UC-NRLF

В ᄅ 9】2 вв 
Digitized by the Internet Archive in 2007 with funding from Microsoft Corporation 
U. S. DEPARTMENT OF AGRICULTURE, BUREAU OF CHEMISTRY-BULLETIN No. 138.

H. W. WILEY, Chief of Bureau.

\section{TRANSLOCATION OF PLANT FOOD AND ELABORA- TION OF ORGANIC PLANT MATERIAL IN WHEAT SEEDLINGS.}

BY

J. A. LE CLERC AND J. F. BREAZEALE, Laboratory of Plant Physiological Chemistry.

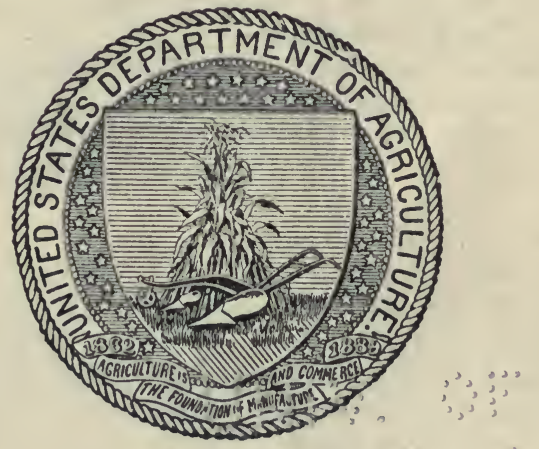

WASHINGTON:

GOVERNMENT PRINTING OFFIOE. 1911. 


\section{ORGANIZATION OF BUREAU OF CHEMISTRY.}

H. W. Wiley, Chemist and Chief of Burcau.

F. L. Dunlap, Associate Chemist; Acting Chief in absence of Chief.

W. D. Bigelow, Assistant Chief of Bureau.

F. B. Linton, Chief Clerk.

A. L. Pierce, Editor.

A. E. Draper, Librarian.

Division of Foods, W. D. Bigelow, Chief.

Food Inspection Laboratory, I. M. Tolman, Chief.

Food Technology Laboratory, E. M. CHACE, Chief, and Assistant Chief of Division.

Oil, Fat, and Wax Laboratory, H. S. BAILEY, Chief.

Division of Drugs, L. F. KeBLer, Chief.

Drug Inspection Laboratory, G. W. Hoover, Chief.

Synthetic Products Laboratory, W. O. Emery, Chief.

Essential Oils Laboratory, under Chief of Division.

Pharmacological Laboratory, Wм. SAlant, Chief.

Chief Food and Drug Inspector, W. G. CAMPBELL.

Miscellaneous Division, J. K. HaYwood, Chief.

Water Laboratory, W. W. Skinner, Chief.

Cattle-Food and Grain Laboratory, G. L. Bidwell, Acting.

Insecticide and Fungicide Laboratory, C. C. MCDonnell, Chief.

Trade Wastes Laboratory, under Chief of Division.

Contracts Laboratory, P. H. Walker, Chief.

Dairy Laboratory, G. E. PATrick, Chief.

Food Research Laboratory, M. E. Pennington, Chief.

Main Lib.

Leather and Paper Laboratory, F. P. VeITCH, Chief.

Microchemical Laboratory, B. J. Howard, Chief.

Physical Chemistry Laboratory, C. S. Hudson, Chief.

Sugar Laboratory, A. H. BryaN, Chief.

Sections:

Animal Physiological Chemistry, F. C. Weber, in Charge.

Bacteriological Chemistry, G. W. Stiles, in Charge.

Enological Chemistry, W. B. Alwood, in Charge.

Nitrogen, T. C. Trescot, in Charge.

Plant Physiological Chemistry, J. A. LE Clerc, Chief.

Food and Drug Inspection Laboratories:

Boston, B. H. Sмгтн, Chief.

Buffalo, W. L. Duвors, Chief.

Chicago, A. L. Winton, Chief.

Cincinnati, B. R. HART, Chief.

Denver, R. S. Hiltner, Chief.

Detroit, H. L. Schulz, Chief.

Galveston, T. F. PAppe, Chief.

Honolulu, Hawtij, .E. B. BuANCHARR, Acting.

Kansas City, Mo:, I: W. Liyps

Nashville, R, W. Batcom Chief.

New York, R. E. Doolitrue, Chief.

Omaha, S. H. Ross, Chief.

Philadelphia, C. S. Brinton, Chief.

Pittsburg, M. C. Albrech, Chief.

Portland, Oreg., A. L. Knisely, Chief.

St. Louis, D. B. Bisbee, Chief.

St. Paul, A. S. Mrtchell, Chief.

San Francisco, R. A. Gould, Chief.

Savannah, W. C. Burnet, Chief.

Seattle, H. M. Loomis, Chief. 


\section{4 \\ $\mathrm{A}_{3}$ \\ no.138-147}

\section{LETTER OF TRANSMITTAL.}

United States Department of Agriculture, Bureau of Chemistry,

Washington, D. C., April 17, 1911.

Sin: I have the honor to submit for your approval the accompanying report of an investigation made by J. A. Le Clerc and J. F. Breazeale, plant physiological chemists of this bureau, on the translocation of plant foods and the elaboration of organic plant material in wheat seedlings. I recommend that this report be published as Bulletin No. 138 of the Bureau of Chemistry.

Respectfully,

Hon. James Wilson,

H. W. Wiley, Chief of Bureau.

Secretary of Agriculture. 



\section{CONTENTS.}

Introduction

Method of growing the seedlings................................. 8

Inorganic constituents...................................... 9

Seedlings grown in distilled water........................... 9

Potash absorption .................................... 9

Amounts of plant food remaining in the seed................... 11

Examination of the entire plant............................. 12

Seedlings grown in nutrient solutions......................... 13

Effect of solution containing one fertilizing element on absorption of plant food........................................ 13

Relative amounts of plant food in plumule and radicle when grown in complete nutrient solution............................... 15

Organic constituents............................................. $\quad 19$

Crude fat................................................ 19

Fiber................................................. ${ }_{22}$

Pentosans................................................. ${ }_{25}$

Reducing sugar and sucrose................................. 28

Appendix................................................ 30

\section{ILLUSTRATIONS.}

FIG. 1. Graph showing decrease in total dry weight of plant and increase in inorganic plant constituents and weight of plumule and radicle ....

2. Graph showing decreasing weight of seed and loss of inorganic plant constituents therein ................................... 



\section{TRANSLOCATION OF PLANT FOOD AND ELABORATION OF INORGANIC PLANT MATERIAL IN WHEAT SEEDLINGS.}

\section{INTRODUCTION.}

The results on the leaching of inorganic plant constituents from plants, especially at the ripening stage, which were published by the authors in the 1908 Yearbook of the department, as well as their unpublished work on the chemical study of field crops, particularly cereals, throughout the whole growing period, have shown the desirability of studying the chemical and physiological changes which take place during the very early stages of plant growth; that is, during the first two weeks after germination.

Investigations on the growth of seedlings have, for the most part, been confined to the respiration, the decomposition of the protein of the plant during germination, and the detection and isolation of various compounds formed in the plants as a direct result of the vital processes. Comparatively little work has been undertaken along the lines of the investigation herein reported, namely, the translocation of the inorganic salts from the seed to the aerial portion of the plant and to the rootlet, their accumulation in the plumule, and the formation of the various organic constituents of the plant.

In 1874 Kellner ${ }^{1}$ made a study of pea seedlings, and was the first to show that the respiration was greater in dilute nitrate solution than in water culture. His analyses of the original and of the steeped pea showed that on steeping an appreciable amount of each of the inorganic constituents was dissolved, and that the amount of soluble organic substances increased, while the actual and total amount of inorganic salts decreased. Iwanow ${ }^{2}$ and Zaleski found that in seedlings grown in the dark the relative amount of inorganic phosphorus increased at the expense of the organic phosphorus. On the other hand, Hart and Andrews ${ }^{3}$ showed the reverse to be true; in other words, that the inorganic phosphorus did not increase, but that there was an increase in soluble organic phosphorus.

During the germination of sunflower and hemp seed in the dark Frankfurt ${ }^{4}$ found that there was an increased formation of lecithins, 
nuclain, sugars, fiber, and pentosans, and a decrease of fat and protein, while the total nitrogen and ash remained unchanged.

De Chalmot, ${ }^{1}$ in his work on cereals, came to the conclusion that pentosans were produced from the sugars, but were not a result of direct assimilation; that the process of their formation did not continue after the death of the plant, and that the pentosans in the seeds were present as reserve material.

Deléano ${ }^{2}$ made a study of the castor-oil bean, with special reference to the behavior of the fat, and found that the fat content remained practically constant up to the eighth day after germination, after which, from the eighth to the fifteenth day, the decrease was very rapid, falling from 17 grams per 100 plants to about 2 grams without at the same time causing any appreciable loss in dry weight. Coincident with the decrease in fat there was noted a rapid increase in water soluble organic substance.

André, ${ }^{3}$ in a recent study of the changes taking place in bulbous plants from the planting of the bulb until the formation of the seed, showed that during the first month the dry weight of the bulb decreased, due to the fact that the aerial portion of the plant feeds on it, but later the bulb increases in weight, owing to the assimilative processes of the aerial portion and the subsequent storage of organic material. During the first month the increase in the ash content was found to be due almost entirely to the absorption of magnesium, calcium, and silicon, the nitrogen and phosphorus having decreased 40 and 17 per cent, respectively. At the end of the first month the aerial portion weighed twice as much as the original bulb, most of the nitrogen and phosphorus having been absorbed from the soil and not drawn from the reserve already present in the bulb. During the latter stages of growth, toward maturation, the plant used the food stored in the stem for the formation of its seed.

\section{METHOD OF GROWING THE SEEDLINGS.}

As it was found (see p. 10) that seeds upon being steeped or soaked excrete quite an amount of nutrient salts, the following method of growing the seedlings was adopted: After the seeds had soaked for several hours the water was drained off and they were spread over a perforated aluminum disk, such as is used in the Bureau of Soils, which consists of a modification of that employed by De Chalmot ${ }^{4}$ in 1894 . The disk was then placed in a shallow pan, so that the seeds came in contact with, but were not submerged by, the water, which was specially distilled and treated with carbon black, so as to prevent any toxic action on the seedlings. The water was changed frequently. 
Besides growing the seedlings in water, as a control, they were also grown in the following culture media:

(a) Nitrate as sodium nitrate $\left(\mathrm{NaNO}_{3}\right)(50$ to 150 parts per million).

(b) Potash as potassium sulphate $\left(\mathrm{K}_{2} \mathrm{SO}_{4}\right)$ (50 to 150 parts per million).

(c) Potash as potassium chlorid $(\mathrm{KCl})$ (50 to 150 parts per million).

(d) Phosphoric acid as sodium phosphate $\left(\mathrm{Na}_{2} \mathrm{HPO}_{4}\right)$ (64 to 150 parts per million).

(e) Complete-

Nitrate $\left(\mathrm{NO}_{3}\right), 50$ parts per million.

Potash $\left(\mathrm{K}_{2} \mathrm{O}\right), 50$ parts per million.

Phosphoric acid $\left(\mathrm{P}_{2} \mathrm{O}_{5}\right)$, 50 parts per million.

The plants were grown for 2 weeks, at room temperature, generally during the winter and spring months, care being taken to grow control plants in distilled water. In about 24 hours the embryo could be seen breaking through the bran coating, and in about 48 hours the plumule and radicle were large enough to be removed from the mother seed. The axes were removed from 100 to 200 seeds every few days, and both the axes and the residual seeds analyzed separately.

\section{INORGANIC CONSTITUENTS.}

\section{SEEDLINGS GROWN IN DISTILLED WATER.}

\section{POTASH ABSORPTION.}

To show with what avidity and activity these little seedlings take up potash, figure 1 was platted. This curve shows that when the seedling was 2 days old and weighed about 6 per cent as much as the whole seed (that is, when 100 axes weighed only 0.2 gram), it had absorbed about 50 per cent of the potash of the original seed, as compared with 25 per cent of nitrogen and 17 per cent of phosphoric acid.

At 4 days, the axes contained almost as much potash as was present in the seed (fig. 2). At the end of 12 days, when the plants were about 6 inches high, and the residual seeds, as shown by figure 2 , had given up 96 per cent of their potash, 83 per cent of their nitrogen, and 80 per cent of their phosphoric acid, the axes contained half again as much potash, 93 per cent as much nitrogen, and 75 per cent as much phosphoric acid as did the original seed. The explanation given of this high absorption of potash is that on steeping, the seeds excrete large amounts of this plant food, which are rapidly absorbed by the seedling, the extra amount of potash coming from the ungerminated seeds. This fact was proved by the following experiment: 10 grams of wheat seeds were shaken with $100 \mathrm{cc}$ of water and allowed 94089 - Bull. $138-11-2$ 
to stand 24 hours. An analysis of the resultant solution gave 100 parts per million of potash, 35 parts per million of phosphoric acid, and 40 parts per million of nitrogen. These figures account in part for the greater proportion of potash that the plant took up even in water culture. The fact that the phosphoric acid found in the plant at the end of 12 days was below that contained in the original seed, simply indicates that while some phosphoric acid is leached from the seeds, the little plants do not require this element at this stage of growth and so do not absorb it to the same extent that they do potash and nitrogen. Figures 1 and 2 are based on results obtained in the

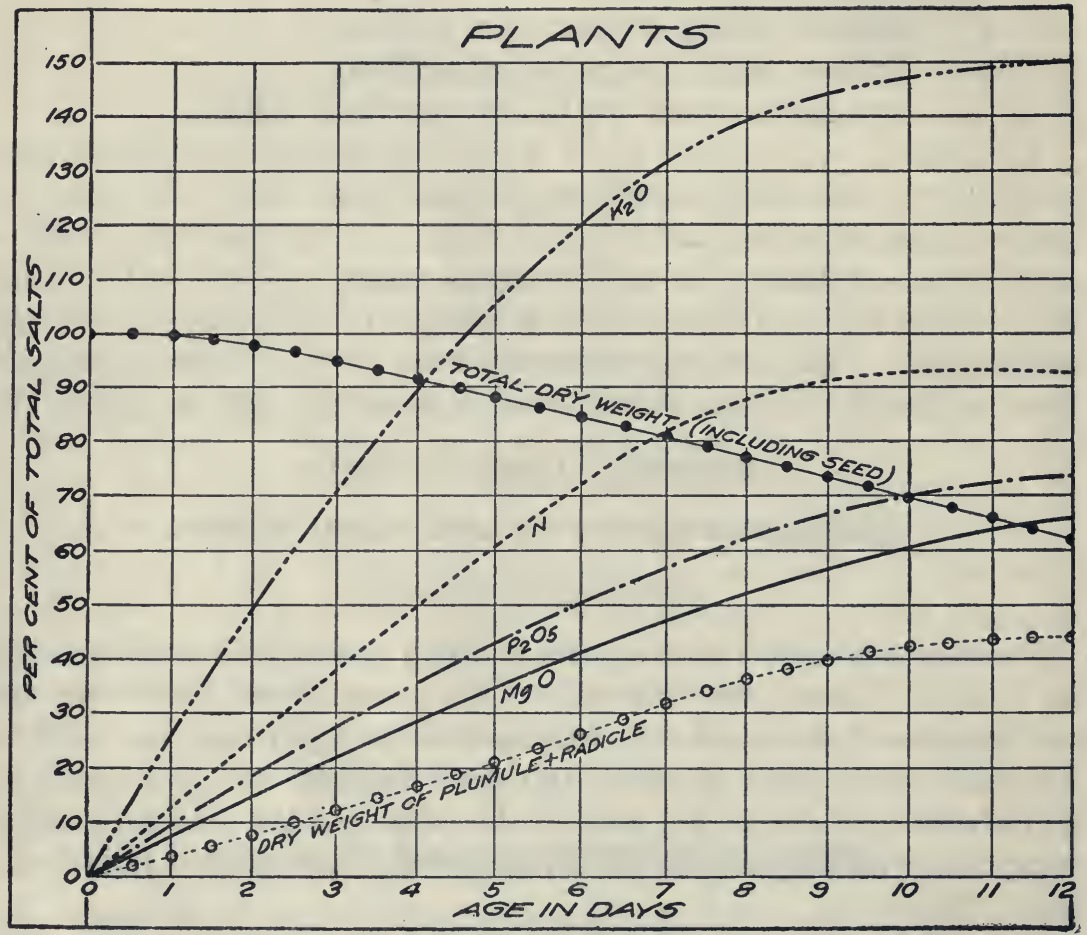

Fig. 1.-Graph showing decrease in total dry weight of plant and increase in inorganic plant constituents and weight of plumule and radicle.

first experiment using distilled water cultures, when no special precautions were taken to prevent the seedlings from assimilating the extraneous salts.

The amount of potash above 100 per cent absorbed by the plant, due to the leaching out of this element from ungerminated seeds, suggested a modification of the method of growing the seedlings. This variation consisted in first steeping the seed for several hours, pouring off the water, resteeping in fresh water, and repeating this change of water at shorter intervals about a dozen times, after which the seeds were spread out on the aluminum disks and allowed to germinate. 
This procedure, which prevented the absorption of most of the readily soluble salts of the ungerminated seeds by the growing seedlings, was followed in the subsequent work. Not only were the seeds given a previous steeping but the solutions in which the seedlings grew were changed more frequently.

AMOUNTS OF PLANT FOOD REMAINING IN THE SEED.

Figure 2 shows the amounts of nitrogen, phosphoric acid, and potash left in the seed at intervals during a period of 12 days and the dry weight of the seed at the corresponding dates. It emphasizes how

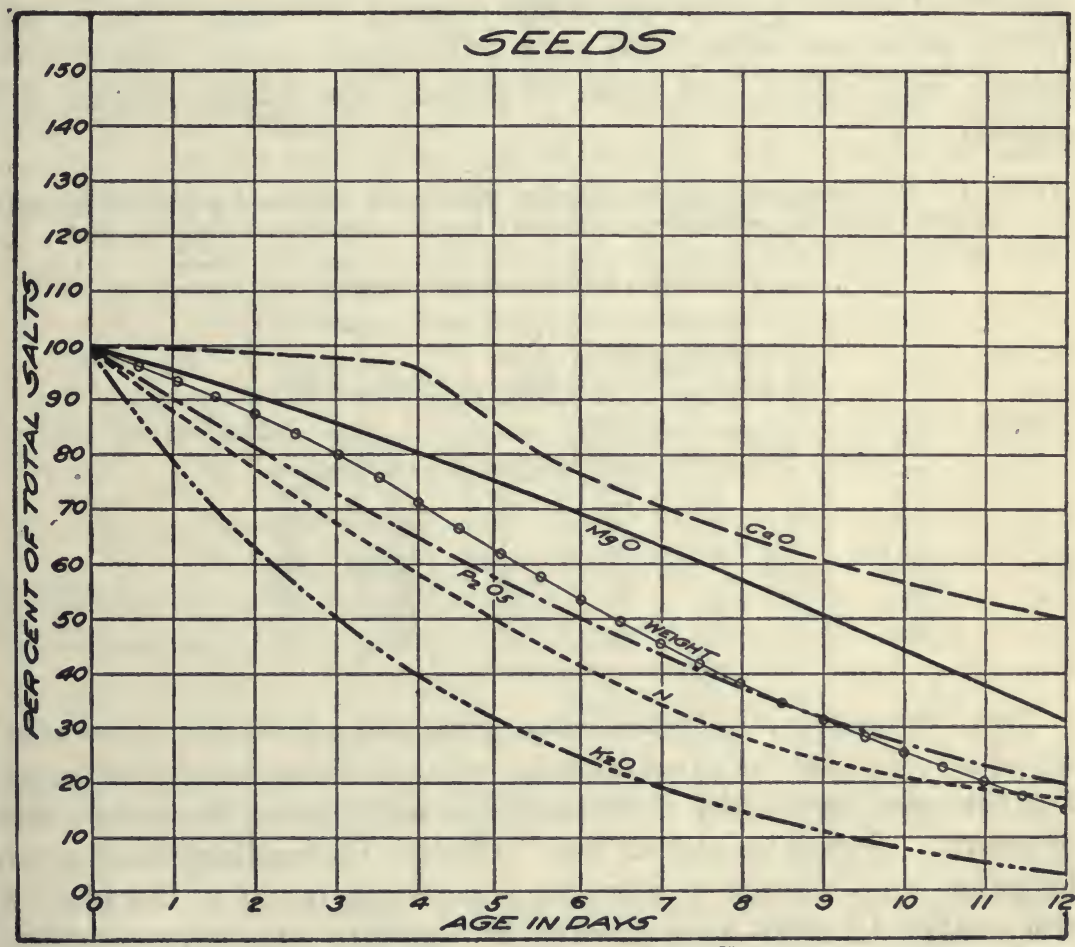

FIG. 2.-Graph showing decreasing weight of seed and loss of inorganic plant constituents therein.

fast the potash of the seed is depleted, the amount left in the seed at the end of 12 days being only 4 per cent of the original quantity, while in the case of nitrogen and phosphoric acid 17 and 20 per cent, respectively, remain.

At the end of 17 days the seeds contained only about 4 per cent of the original amounts of nitrogen, of phosphoric acid, and of potash; the report of the Microchemical Laboratory stated that the residual seed consisted of a mass of disorganized aleurone layers and bran, the cells appearing to be empty except for globules of oil. If platted at this period, and subsequently thereto, the curve would have 
assumed a horizontal position, and it would seem that further absorption of salts from the seeds was an impossibility, indicating that the small amounts of salts and of nitrogen left in the seed coating or bran are the most difficult of absorption.

\section{EXAMINATION OF THE ENTIRE PLANT.}

Table 1 shows the amount of nitrogen, phosphoric acid, and potash in the whole plant, including the axes and the residual seed, these figures being obtained on seedlings grown in distilled water, after being thoroughly steeped in many changes of water. The figures are expressed as the percentage of the original amounts, namely, seeds 100 of which contained 0.051 gram of nitrogen, 0.0328 gram of phosphoric acid, and 0.0194 gram of potash; and which weighed 3.50 grams.

TABLE 1.-Percentage amounts of nitrogen, phosphoric acid, and potash in the entire plant (plumule + radicle +residual seed), based on amounts in original seed.

[Grown in distilled water after steeping.]

\begin{tabular}{|r|r|r|r|r|}
\hline $\begin{array}{r}\text { Age of } \\
\text { plant. }\end{array}$ & Nitrogen. & $\begin{array}{c}\text { Phos- } \\
\text { phoric } \\
\text { acid. }\end{array}$ & Potash. & Weight. \\
\hline Days. & Per cent. & Per cent. & Per cent. & Per cent. \\
2 & 109 & 98 & 96 & 100 \\
3 & 104 & 100 & 112 & 93 \\
4 & 105 & 98 & 133 & 92 \\
5 & 108 & $\ldots . .2 \ldots$ & 130 & 86 \\
6 & 116 & 99 & 130 & 83 \\
7 & 121 & 98 & 124 & 79 \\
9 & 121 & 93 & 138 & 75 \\
12 & 120 & 95 & 138 & 64 \\
\hline
\end{tabular}

This table shows that even when grown in water the entire plant (residual seed plus the axes) takes up an appreciable amount of potash and nitrogen, but hardly any phosphoric acid, during the early stages of growth. It will be noticed that, although the seedlings were grown in water, the amounts of nitrogen and potash found in the plant at the end of 12 days were greater by one-fifth and over one-third, respectively, than those found in the original seed. This is due to the fact that both germinated and ungerminated seeds lost through leaching a certain amount of the salts which they contained, and that some of these salts were absorbed by the seedlings, as before explained. Experiments have demonstrated that much the greater portion of soluble plant food is removed by the first few hours of steeping, but that some inorganic constituents continue to be produced by cleavage from organic compounds, even after several changes in steep water have been made. It is seen, therefore, that it is almost impossible to eliminate the slight error due to the excretion of salts from the seeds. 
The weight of the entire plant gradually decreased from the beginning, until after 12 days a loss of approximately 40 per cent was recorded.

\section{SEEDLINGS GROWN IN NUTRIENT SOLUTIONS.}

\section{EFFECT OF SOLUTION CONTAINING ONE FERTILIZING ELEMENT ON ABSORPTION OF PLANT FOOD.}

Table 2 shows the effect of growing seedlings in solutions containing only one fertilizing element on the absorption of that constituent by the plant, and likewise on the absorption of the other constituents dissolved from the seeds, as compared with the absorption of these same elements by plants grown in water cultures. The solutions used contained, respectively, 100 and 150 parts per million of nitrate in the form of sodium nitrate, 64 and 150 parts per million of phosphoric acid in the form of sodium phosphate, and 50 and 150 parts per million of potash in the form of potassium chlorid.

TABLE 2.-Amounts of nitrogen, phosphoric acid, and potash in the axes (plumule +radicle) at the end of 9 days, when grown in different nutrient solutions. ${ }^{1}$

\begin{tabular}{|c|c|c|c|c|c|c|}
\hline \multirow[b]{2}{*}{ Constituents and total weight. } & \multicolumn{6}{|c|}{ Nitrate solutions. } \\
\hline & $\begin{array}{l}\text { Water } \\
\text { control. }\end{array}$ & $\begin{array}{l}100 \text { parts } \\
\text { NOs per } \\
\text { million. }\end{array}$ & $\begin{array}{l}\text { Increase } \\
\text { based on } \\
\text { water } \\
\text { control. }\end{array}$ & $\begin{array}{l}\text { Water } \\
\text { control. }\end{array}$ & $\begin{array}{l}150 \text { parts } \\
\text { NO per } \\
\text { million. }\end{array}$ & $\begin{array}{l}\text { Increase } \\
\text { based on } \\
\text { water } \\
\text { control. }\end{array}$ \\
\hline 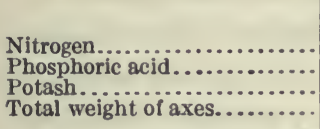 & $\begin{array}{c}\text { Grams. } \\
0.0466 \\
.0236 \\
.0173 \\
1.490\end{array}$ & $\begin{array}{c}\text { Grams. } \\
0.0668 \\
.0270 \\
.0192 \\
1.706\end{array}$ & $\begin{array}{r}\text { Per cent. } \\
43 \\
14 \\
11 \\
14\end{array}$ & $\begin{array}{c}\text { Grams. } \\
0.0446 \\
.0240 \\
: 0186 \\
1.294\end{array}$ & $\begin{array}{c}\text { Grams. } \\
0.0600 \\
.0277 \\
.0202 \\
1.456\end{array}$ & $\begin{array}{r}\text { Per cent. } \\
35 \\
15 \\
9 \\
12\end{array}$ \\
\hline \multirow{2}{*}{ Constituents and total weight. } & \multicolumn{6}{|c|}{ Phosphoric-acid solutions. } \\
\hline & $\begin{array}{l}\text { Water } \\
\text { control. }\end{array}$ & $\begin{array}{l}64 \text { parts } \\
\mathrm{P}_{2} \mathrm{O}_{5} \text { per } \\
\text { million. }\end{array}$ & $\begin{array}{l}\text { Increase } \\
\text { based on } \\
\text { water } \\
\text { control. }\end{array}$ & $\begin{array}{l}\text { Water } \\
\text { control. }\end{array}$ & $\begin{array}{l}150 \text { parts } \\
\mathrm{P}_{2} \mathrm{O}_{6} \text { per } \\
\text { million. }\end{array}$ & $\begin{array}{l}\text { Increase } \\
\text { based on } \\
\text { water } \\
\text { control. }\end{array}$ \\
\hline 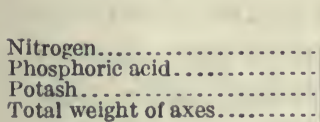 & $\begin{array}{l}\text { Grams. } \\
0.0471 \\
.0260 \\
.0216 \\
1.435\end{array}$ & $\begin{array}{r}\text { Grams. } \\
0.0500 \\
.0350 \\
.0201 \\
1.667\end{array}$ & $\begin{array}{r}\text { Per cent. } \\
55 \\
35 \\
0 \\
11\end{array}$ & $\begin{array}{c}\text { Grams. } \\
0.0477 \\
.0282 \\
.0216 \\
1.594\end{array}$ & $\begin{array}{r}\text { Grams. } \\
0.0460 \\
.0355 \\
.0217 \\
1.654\end{array}$ & $\begin{array}{r}\text { Per cent. } \\
0 \\
26 \\
0 \\
4\end{array}$ \\
\hline
\end{tabular}

Potash solutions.

\begin{tabular}{|c|c|c|c|c|c|c|}
\hline \multirow[b]{2}{*}{ Constituents and total weight. } & \\
\hline & $\begin{array}{l}\text { Water } \\
\text { control. }\end{array}$ & $\begin{array}{l}50 \text { parts } \\
\mathbf{K}_{2} \mathrm{O} \text { per } \\
\text { million. }\end{array}$ & $\begin{array}{l}\text { Increase } \\
\text { based on } \\
\text { water } \\
\text { control. }\end{array}$ & $\begin{array}{l}\text { Water } \\
\text { control. }\end{array}$ & $\begin{array}{l}150 \text { parts } \\
\mathbf{K}_{2} \mathrm{O} \text { per } \\
\text { million. }\end{array}$ & $\begin{array}{l}\text { Increase } \\
\text { based on } \\
\text { water } \\
\text { control. }\end{array}$ \\
\hline 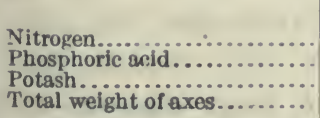 & $\begin{array}{r}\text { Grams. } \\
0.0460 \\
.0202 \\
.0202 \\
1.256\end{array}$ & $\begin{array}{r}\text { Grams. } \\
0.0466 \\
.0244 \\
.0607 \\
1.444\end{array}$ & $\begin{array}{r}\text { Per cent. } \\
1 \\
20 \\
200 \\
15\end{array}$ & $\begin{array}{r}\text { Grams. } \\
0.0488 \\
.0255 \\
.0231 \\
1.526\end{array}$ & $\begin{array}{c}\text { Grams. } \\
0.0443 \\
.0278 \\
.0558 \\
1.740\end{array}$ & $\begin{array}{r}\text { Per cent. } \\
0 \\
9 \\
140 \\
14\end{array}$ \\
\hline
\end{tabular}


The seedlings were grown nine days, a set of controls being grown in distilled water in every case. The table gives the percentage of increased absorption of each salt under the various conditions as compared to that observed in the case of the plants grown in the control solutions. The results show that when nitrates are present the absorption of that element by the axes is from 35 to 43 per cent greater than it is in a water culture containing no nitrates; when phosphates are present the absorption is increased from 26 to 35 per cent, and when potash is present the avidity which young plants display for this element causes it to absorb from 140 to 200 per cent more of this constituent than when grown in a water culture. It will also be noted that the presence of nitrates not only causes an increased nitrate absorption, but also seems to produce a slight increased absorption of potash and phosphoric acid.

The curve platted in figure 2 indicates that on the ninth day the seed grown in water still retained about 30 per cent of its original amount of phosphate. Part of this amount seems to have been given up to the plantlet under the influence of the nitrate stimulus. The same fact is noted when potash is added to the solution. In this case an increased absorption of from 140 to 200 per cent of potash, and of from 10 to 20 per cent of phosphoric acid occurs. No appreciable increase in absorption of nitrogen or potash is noted under the phosphoric-acid stimulus.

Another point to be observed is that the presence of 150 parts per million of phosphoric acid, nitrate, or potash, respectively, in the solution did not cause any increased absorption of any one salt by the plant over what was taken up when it grew in a solution containing only from 50 to 100 parts per million, showing that as long as the little plant has plenty of food at its command the addition of a larger amount will not cause it to absorb a correspondingly larger quantity. As the table shows, the amount of potash absorbed by the plant growing in the potash solution is far greater than the amount of nitrogen and phosphoric acid absorbed by the plants grown in the nitrate and phosphoric acid solutions, respectively. At the end of nine days the plant.contains approximately three times as much potash as was present in the original seed, or an increase of about 200 per cent, which leads to the conclusion that plants need large amounts of potash during the early stages of growth.

Another possible conclusion to be drawn from this table is that young plants do not absorb a very great amount of phosphates even when these salts are present in rather large quantities. The nitrates are taken up somewhat more readily than the phosphates, but not nearly to the extent that potash is absorbed. In other words, the plants exert a selective absorption, assimilating a large amount of 
potash, not merely because it is at their command, but because they need the potash right then and there for the proper exercise of their physiological functions.

Regarding the increase in the weight of the plants, the table shows that the addition of any one salt produces an increased growth of from 12 to 14 per cent in dry weight in nitrate solution; of from 4 to 11 per cent in the phosphate solution; and of from 14 to 15 per cent in the potash solution. Although the seedlings take up a much larger amount of potash than of nitrogen and phosphate, it has been noted that the plants growing in the potash solution are inferior in color and in luxuriance to those grown in the other two solutions. The plants grown in the nitrate solution look the hardiest; having the best color and apparently the most green matter, while those in the phosphate solution are intermediate. No great difference was noted between the dry weight of 100 plants 12 days old, as grown in the three different culture solutions.

RELATIVE AMOUNTS OF PLANT FOOD IN PLUMUlE AND RADICLE WHEN GROWN IN COMPLETE NUTRIENT SOLUTION.

One experiment was conducted in order to determine the relative amounts of nitrogen, phosphoric acid, and potash absorbed by the radicle and translocated to, and accumulated in, the plumule, and the amounts remaining in the radicle itself at different stages of growth. This experiment was carried on both in a complete nutrient solution and in distilled water, the latter serving as the control. The weather being rather warm, the seedlings were grown in the control solution for only seven days, having at the end of this period attained about the size of seedlings twice that age when grown at a lower temperature. The seedlings in the nutritive solution, however, although grown at the same temperature, were allowed to develop for 15 days. In order to determine the amounts of salts translocated from the seed into the plumule and radicle, respectively, several hundred axes were separated from the seed and then further divided into the radicle and plumule. The results obtained are shown in the table following; all nitrogen determinations were made by T. C. Trescot. 
TABLE 3.-Relative amounts of plant material in the plumule and radicle during first 15 days' growth.

WATER CULTURE.

\begin{tabular}{|c|c|c|c|c|c|c|c|c|}
\hline \multirow[b]{2}{*}{$\begin{array}{l}\text { Part of plant and } \\
\text { age. }\end{array}$} & \multicolumn{2}{|c|}{ Nitrogen. } & \multicolumn{2}{|c|}{ Phosphoric acid. } & \multicolumn{2}{|c|}{ Potash. } & \multicolumn{2}{|c|}{ Weight. } \\
\hline & $\begin{array}{l}\text { Amount } \\
\text { per } 100 \\
\text { plants. }\end{array}$ & $\begin{array}{c}\text { Per cent } \\
\text { of amount } \\
\text { in origi- } \\
\text { nal seed. }\end{array}$ & $\begin{array}{l}\text { Amount } \\
\text { per } 100 \\
\text { plants. }\end{array}$ & $\begin{array}{c}\text { Per cent } \\
\text { of amount } \\
\text { in origi- } \\
\text { nal seed. }\end{array}$ & $\begin{array}{l}\text { Amount } \\
\text { per } 100 \\
\text { plants. }\end{array}$ & $\begin{array}{c}\text { Per cent } \\
\text { of amount } \\
\text { in origi- } \\
\text { nal seed. }\end{array}$ & $\begin{array}{l}\text { Weight } \\
\text { per } 100 \\
\text { plants. }\end{array}$ & $\begin{array}{l}\text { Per cent } \\
\text { based on } \\
\text { weight of } \\
\text { original } \\
\text { seed. }\end{array}$ \\
\hline 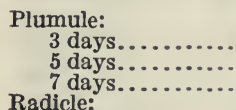 & $\begin{array}{r}\text { Grams. } \\
0.0207 \\
.0348 \\
.0365\end{array}$ & $\begin{array}{l}40 \\
69 \\
73\end{array}$ & $\begin{array}{r}\text { Grams. } \\
0.0082 \\
.0167 \\
.0215\end{array}$ & $\begin{array}{l}25 \\
50 \\
65\end{array}$ & $\begin{array}{r}\text { Grams. } \\
0.0117 \\
.0190 \\
.0194\end{array}$ & $\begin{array}{l}59 \\
95 \\
97\end{array}$ & $\begin{array}{r}\text { Grams. } \\
0.466 \\
.895 \\
1.141\end{array}$ & $\begin{array}{l}13 \\
27 \\
33\end{array}$ \\
\hline $\begin{array}{r}3 \text { days............ } \\
5 \text { days............. } \\
7 \text { days........... } \\
\text { Axis (plumule+rad- } \\
\text { icle)! }\end{array}$ & $\begin{array}{l}.0118 \\
.0146 \\
.0163\end{array}$ & $\begin{array}{l}23 \\
29 \\
32\end{array}$ & $\begin{array}{l}.0058 \\
.0070 \\
.0090\end{array}$ & $\begin{array}{l}17 \\
21 \\
27\end{array}$ & $\begin{array}{l}.0048 \\
.0036 \\
.0047\end{array}$ & $\begin{array}{l}24 \\
18 \\
24\end{array}$ & $\begin{array}{l}.335 \\
.481 \\
.629\end{array}$ & $\begin{array}{l}10 \\
14 \\
18\end{array}$ \\
\hline 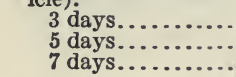 & $\begin{array}{l}.0325 \\
.0494 \\
.0528\end{array}$ & $\begin{array}{r}65 \\
98 \\
104\end{array}$ & $\begin{array}{l}.0140 \\
.0237 \\
.0305\end{array}$ & $\begin{array}{l}43 \\
72 \\
93\end{array}$ & $\begin{array}{l}.0165 \\
.0226 \\
.0241\end{array}$ & $\begin{array}{r}83 \\
113 \\
121\end{array}$ & $\begin{array}{r}.801 \\
1.376 \\
1.742\end{array}$ & $\begin{array}{l}23 \\
40 \\
50\end{array}$ \\
\hline
\end{tabular}

NUTRIENT SOLUTION.

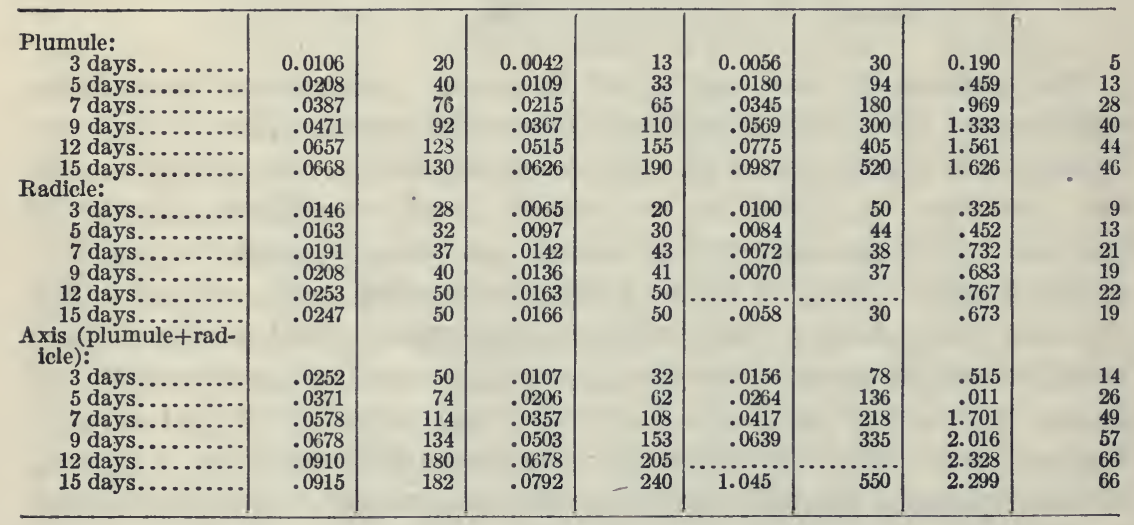

In the water culture (Table 3 ) the weight of the plumule and the radicle together increased daily at a much slower rate than did the absorption of nitrogen, phosphoric acid, and potash; that is, while the weight increased from 23 to 50 per cent the nitrogen increased from 65 to 104 per cent, the phosphoric acid from 43 to 93 percent, and the potash from 83 to 121 per cent. In the nutrient solution the behavior was similar, only somewhat more pronounced.

Considering the relative amounts of nitrogen, phosphoric acid, and potash in the plumule and radicle, respectively, the table shows that in distilled water the weight of the plumule increased at a slower rate than did the translocation and accumulation of nitrogen, phosphoric acid, and potash.

In the case of the radicle the increase in weight is only a little less than the increase in the retention of nitrogen, phosphoric acid, and 
potash which have been absorbed; that is, while therwegght of the radicle increases from 10 to 18 per cent the increase of phosphoric acid ranges from 17 to 27 per cent, the increase in titrogen varies between 23 and 32 per cent, and the amount of potash remains practically constant at about 24 per cent. The amounts of nitrogen, phosphoric acid, and potash in the radicle indicate that almost as soon as absorbed these elements are translocated to the plumule, where they can be utilized during the subsequent processes of assimilation and plant growth.

At the age of three days in the water culture the weights of the plumule and radicle are about equal; the plumule has, however, about twice as much nitrogen and potash and a half again as much phosphoric acid as is present in the radicle.

At the end of seven days the plumule weighs almost twice as much as the radicle, contains over twice as much nitrogen and phosphoric acid, and about four times as much potash, showing that potash is the element especially accumulated in the plumule.

The latter part of Table 3 shows to what extent these conditions are accentuated when seedlings are grown in a nutrient solution. On the fifth day of the experiment the weights of the plumule and of the radicle were almost identical and the amounts of nitrogen and phosphoric acid in each were approximately the same, and the potash in the plumule was about twice that in the radicle. At the end of 15 days the plumule weighed more than twice as much as the radicle and contained over $2 \frac{1}{2}$ times as much nitrogen, nearly 4 times as much phosphoric acid, and about 17 times as much potash. This is a most striking illustration of how the absorbed salts are moved from the radicle to the plumule and there accumulated; especially is this true of the potash, and when taken in connection with the rapid breaking down of the starch and sugars (see p. 28) would seem to indicate that potash plays the chief physiological rôle in these changes.

There was a steady increase in the weights of the plumule and in the amount of nitrogen, phosphoric acid, and potash therein, the weight increasing 9 times, the nitrogen almost 7 times, the phosphoric acid about 15 times, and the potash about 17 times. The weight of the radicle increased twice, the nitrogen was almost double, and the phosphoric acid increased $2 \frac{1}{2}$ times, while the potash actually showed a decrease, thus indicating that as far as this constituent is concerned, the plumule is really the seat of physiological action.

A further comparison of these data shows that at the beginning of the experiment the weights of the radicles and the amounts of nitrogen and phosphoric acid therein in the case of the seedlings grown in distilled water are about the same respectively as the figures found for the radicles of the seedlings grown in the nutrient solution. The 
radicles grown in water culture, however, contain only half as much potash as those grown in the complete medium. At the end of the experiment, while the weights of the radicles grown in water and the amounts of potash are about the same as for the radicles of the nutrient solution, the amounts of nitrogen and phosphoric acid are less for the former than for the latter. The differences are not, however, very great in any case, thus indicating that the rootlets up to this age do not retain the plant food absorbed. Comparing the plumules, those grown in distilled water contain about one-half as much nitrogen, one-third as much phosphoric acid, and not quite one-fifth as much potash as do those grown in the nutrient solution.

Of the inorganic constituents found in the axes of the seedlings grown in a nutritive solution, the following proportions occur in the plimmule:

TABLE 4.-Percentage of inorganic constituents of the axis that occur in the plumule.

(Seedlings grown in complete nutritive solution.)

\begin{tabular}{|r|r|r|r|r|}
\hline Age. & Nitrogen. & $\begin{array}{c}\text { Phos- } \\
\text { phoric } \\
\text { acid. }\end{array}$ & Potash. & Weight. \\
\hline Days. & Per cent. & Per cent. & Per cent. & Grams. \\
3 & 42 & 42 & 36 & 37 \\
5 & 56 & 53 & 68 & 50 \\
7 & 67 & 60 & 80 & 56 \\
9 & 70 & 72 & 89 & 66 \\
12 & 72 & 76 & $\ldots . .6 \%$ & 67 \\
15 & 72 & 79 & 94 & 71 \\
\hline
\end{tabular}

The complementary percentages are, of course, the amounts found in the radicle. Here again it is seen that potash is rapidly stored up in the plumule, at a much faster rate than the weight increases or than the nitrogen and phosphoric acid accumulate.

Just why the seedling absorbs potash with such avidity and accumulates it so rapidly in the plumule is at present a matter of mere conjecture. At this early stage of development starch destruction in the seed is marked, and there is equally great activity in starch, sugar, and fiber formation and elaboration in the plumule. It is not at all improbable that through centuries of successful combat the plant has acquired this fixed characteristic which has proved its salvation, namely, the accumulation of plant food, especially of potash at an early stage, thus placing itself in a position later to elaborate its own food material with the aid of the sun's rays and the carbon dioxid in the air.

Before concluding the consideration of the inorganic constituents, some mention of similar work done with ordinary beans (Phaseolus vulg.), and lima beans (Phaseolus lunatus) may be of interest. The results obtained with these seeds show less regularity, however, because it is more difficult to obtain samples of such uniformity as 
in the case of wheat seedlings. The results show, nevertheless, that in 15 days, in the case of ordinary beans, 80 per cent of the nitrogen, 84 to 90 per cent of the potash, and 70 to 75 per cent of the phosphoric acid are removed from the endosperm, again indicating the greater mobility of the potash.

\section{ORGANIC CONSTITUENTS.}

Comparatively little work has been done on the changes in the organic constituents during the first two weeks of the seedling's life, except that of André, Deléano, De Chalmot, and others, of which mention has already beer made. The same solutions were used in growing these seedlings as in the case of the preceding study on the inorganic constituents (see p. 9), and in addition the following were also employed: Complete solution less nitrate; complete solution less phosphoric acid; complete solution less potash.

The resultant crops were separated at regular intervals of a few days into axes and residual seeds, each portion being analyzed for ether extract, fiber, pentosans, and sugars before and after inversion.

The 100 original seeds weighed 3.5 grams and contained 0.069 gram of ether extract, 0.079 gram of fiber, 0.256 gram of pentosans, and 0.095 gram of sugar after hydrolysis.

\section{CRUDE FAT.}

Referring to the weights given in Table 6, the residual seeds of the seedlings grown in the control solution are seen to contain on the average from 60 to 67 per cent of the original crude fat of the seed, thus indicating that this amount of nonembryonic crude fat is not absorbable by the plant.

Comparing these amounts with those found in the residual seeds of plantlets grown in the complete nutritive solution and in the solutions containing but one plant food constituent, very small differences are noted, as follows: The average amounts of nonembryonic crude fat remaining after 15 days' growth in the seedlings started March 29 were as follows: Grown in the control solution 60 per cent, in potash solution 62, and in phosphate 65 per cent. Those started on April 11, in control solution 68 , in nitrate 60 , and in complete solution 60 per cent. The difference in the season of growth accounts for the differences in the figures given, as it is impossible to have all the conditions affecting growth the same at different times. However, inasmuch as the control seedlings in Table 6 give about the same data for ether extract as the potash and phosphate seedlings or those grown in the nitrate and complete solutions, it is plainly indicated that the presence of plant food exerts but little influence on the decomposition and translocation of the fat material from the seed to the axes. The average amount of nonembryonic fat in the seed is thus seen to be 
about 60 per cent. The per cent of fat in the axes, based on the amount present in the original seed, is shown in the following table:

TABLE 5.-Relative amounts of fat in the axes when grown in varying nutrient solutions (based on original amount in seed).

\begin{tabular}{|r|r|r|r|r|r|r|}
\hline $\begin{array}{c}\text { Age of } \\
\text { plant. }\end{array}$ & $\begin{array}{c}\text { Control } \\
\text { solution. }\end{array}$ & $\begin{array}{c}\text { Potash } \\
\text { solution. }\end{array}$ & $\begin{array}{c}\text { Phosphor- } \\
\text { ic solu- } \\
\text { tion. }\end{array}$ & Control. & $\begin{array}{c}\text { Nitrate } \\
\text { solution. }\end{array}$ & $\begin{array}{c}\text { Complete } \\
\text { solution. }\end{array}$ \\
\hline Days. & Per cent. & Per cent. & Per cent. & Per cent. & Per cent. & Per cent. \\
5 & 34 & 31 & 34 & 34 & 30 & 52 \\
7 & 51 & 52 & 66 & 48 & 64 & 61 \\
9 & 70 & 60 & 87 & 65 & 89 & 86 \\
12 & 73 & 73 & 85 & $\ldots . . . . . . . . .$. & 98 \\
15 & 70 & 79 & 91 & 66 & 94 & 103 \\
\hline
\end{tabular}

At five days practically the same amount of ether-extract substance is found in the axes of the seedlings grown in the nitrate, potash, and phosphoric acid solutions as in the control. Those grown in the complete solution, however, contain considerably more fat than the others, the reason for which is that plants grown in the complete medium are about as large at 5 days as those grown in the other solutions are in 7 days. At the end of 15 days it is seen that the axes of seedlings grown in the control solution contain about 70 per cent of the amount of fat present in the original seed, while those of the potash solution contain 79 per cent, those of the phosphate solution 91 per cent, of the nitrate. solution 94 per cent, and of the complete solution 103 per cent. It is thus seen that more substances soluble in ether are formed in the same length of time under the influence of nitrates and phosphates than under that of potash. This is to some extent due to the greater amount of chlorophyll bodies found in the first two instances; the plants grown in the potash solution were never so green nor so luxuriant as those in the nitrate, the phosphate, or complete solution.

From Table 6 it is seen that, based on the dry weight of the seedlings, the per cent of fat found in the axes of the plants grown in the various solutions at the end of 15 days is as follows: In the controls, 3 and 3.2 ; in the potash solution, 3.1 ; in phosphate, 3.6 ; in nitrate, 3.7; and in complete solution, 3.7. Thus, while the nonembryonic fat to the extent of 60 to 67 per cent of the original amount remains constant and unabsorbed in the seed, the axes, beginning with from 30 to 35 per cent of embryonic fat (based on the amount in the original seed), have, at the end of 15 days, increased this amount to from 70 to 103 per cent, this extra amount being formed by the process of assimilation. The largest amount was elaborated by the seedling grown in nitrate and in phosphate solutions, which salts seem to stimulate the production of ether-soluble substances to some extent. Mention has already been made of the fact that the plants grown in 
the nitrate and phosphate solutions were much hardier and had a healthier appearance than those grown in the potash solution.

TABLE 6.-Dry weight and ether extract of seeds, axes, and total plants when grown for 15 days in different nutrient solutions.

STARTED MARCH 29 .

\begin{tabular}{|c|c|c|c|c|c|c|c|c|c|}
\hline \multirow{3}{*}{ Parts of plant and age. } & \multicolumn{3}{|c|}{ Control solution. } & \multicolumn{3}{|c|}{ Potash solution. } & \multicolumn{3}{|c|}{ Phosphate solution. } \\
\hline & \multirow{2}{*}{$\begin{array}{l}\text { Weight } \\
\text { of } 100 .\end{array}$} & \multicolumn{2}{|c|}{ Ether extract. } & \multirow{2}{*}{$\begin{array}{l}\text { Weight } \\
\text { of } 100 .\end{array}$} & \multicolumn{2}{|c|}{ Ether extract. } & \multirow{2}{*}{$\begin{array}{l}\text { Weight } \\
\text { of } 100 .\end{array}$} & \multicolumn{2}{|c|}{ Ether extract. } \\
\hline & & Grams. & $\begin{array}{l}\text { Per } \\
\text { cent. }\end{array}$ & & Grams. & $\begin{array}{c}\text { Per } \\
\text { cent. }\end{array}$ & & Grams. & $\begin{array}{c}\text { Per } \\
\text { cent. }\end{array}$ \\
\hline Original seed .......... & $\begin{array}{r}\text { Grams. } \\
3.50\end{array}$ & 0.0686 & 2.0 & $\begin{array}{r}\text { Grams. } \\
3.50\end{array}$ & 0.0686 & 2.0 & $\begin{array}{r}\text { Grams. } \\
3.50\end{array}$ & 0.0686 & 2.0 \\
\hline 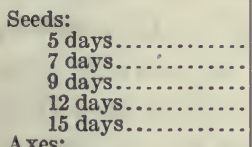 & $\begin{array}{r}1.89 \\
1.38 \\
.93 \\
.62 \\
.36\end{array}$ & $\begin{array}{l}.0470 \\
.0450 \\
.0450 \\
.0445 \\
.0412\end{array}$ & $\begin{array}{r}2.5 \\
3.3 \\
4.8 \\
7.2 \\
11.4\end{array}$ & $\begin{array}{r}2.00 \\
1.48 \\
1.04 \\
.70 \\
.38\end{array}$ & $\begin{array}{l}.0483 \\
.0461 \\
.0456 \\
.0466 \\
.0425\end{array}$ & $\begin{array}{r}2.5 \\
3.1 \\
4.4 \\
6.7 \\
11.1\end{array}$ & $\begin{array}{r}1.74 \\
1.29 \\
.80 \\
.49 \\
.36\end{array}$ & $\begin{array}{l}.0435 \\
.0458 \\
.0450 \\
.0510 \\
.0447\end{array}$ & $\begin{array}{r}2.5 \\
3.6 \\
5.6 \\
10.5 \\
12.4\end{array}$ \\
\hline 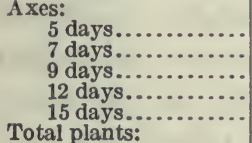 & $\begin{array}{l}1.13 \\
1.34 \\
1.54 \\
1.56 \\
1.48\end{array}$ & $\begin{array}{l}.0235 \\
.0353 \\
.0480 \\
.0500 \\
.0478\end{array}$ & $\begin{array}{l}2.1 \\
2.6 \\
3.1 \\
3.2 \\
3.2\end{array}$ & $\begin{array}{l}1.10 \\
1.42 \\
1.51 \\
1.73 \\
1.77\end{array}$ & $\begin{array}{l}.0210 \\
.0360 \\
.0410 \\
.0500 \\
.0542\end{array}$ & $\begin{array}{l}1.9 \\
2.5 \\
2.7 \\
2.9 \\
3.1\end{array}$ & $\begin{array}{l}1.20 \\
1.55 \\
1.95 \\
1.76 \\
1.87\end{array}$ & $\begin{array}{l}.0237 \\
.0453 \\
.0600 \\
.0581 \\
.0625\end{array}$ & $\begin{array}{l}2.0 \\
2.9 \\
3.1 \\
3.3 \\
3.6\end{array}$ \\
\hline $\begin{array}{l}5 \text { days...... } \\
7 \text { days..... } \\
9 \text { days.... } \\
12 \text { days.... } \\
15 \text { days... }\end{array}$ & $\begin{array}{l}3.02 \\
2.72 \\
2.47 \\
2.18 \\
1.84\end{array}$ & $\begin{array}{l}.0705 \\
.0803 \\
.0930 \\
.0945 \\
.0890\end{array}$ & $\begin{array}{l}2.3 \\
3.0 \\
3.8 \\
4.3 \\
4.8\end{array}$ & $\begin{array}{l}3.10 \\
2.90 \\
2.55 \\
2.43 \\
2.15\end{array}$ & $\begin{array}{l}.0693 \\
.0821 \\
.0866 \\
.0966 \\
.0967\end{array}$ & $\begin{array}{l}2.2 \\
2.8 \\
3.4 \\
4.0 \\
4.5\end{array}$ & $\begin{array}{l}2.94 \\
2.84 \\
2.75 \\
2.25 \\
2.23\end{array}$ & $\begin{array}{l}.0672 \\
.0911 \\
.1050 \\
.1091 \\
.1072\end{array}$ & $\begin{array}{l}2.3 \\
3.2 \\
3.8 \\
4.8 \\
4.8\end{array}$ \\
\hline
\end{tabular}

STARTED APRIL 11.

\begin{tabular}{|c|c|c|c|c|c|c|c|c|c|}
\hline \multirow{3}{*}{ Parts of plant and age. } & \multicolumn{3}{|c|}{ Control solution. } & \multicolumn{3}{|c|}{ Nitrate solution. } & \multicolumn{3}{|c|}{ Complete solution. } \\
\hline & \multirow{2}{*}{$\begin{array}{l}\text { Weight of } \\
100 .\end{array}$} & \multicolumn{2}{|c|}{ Ether extract. } & \multirow{2}{*}{$\begin{array}{c}\text { Weight of } \\
100 .\end{array}$} & \multicolumn{2}{|c|}{ Ether extract. } & \multirow{2}{*}{$\begin{array}{c}\text { Weight of } \\
100 .\end{array}$} & \multicolumn{2}{|c|}{ Ether extract. } \\
\hline & & Grams. & $\begin{array}{c}\text { Per } \\
\text { cent. }\end{array}$ & & Grams. & $\begin{array}{c}\text { Per } \\
\text { cent. }\end{array}$ & & Grams. & $\begin{array}{c}\text { Per } \\
\text { cent. }\end{array}$ \\
\hline Original seed..... & $\begin{array}{r}\text { Grams. } \\
3.50\end{array}$ & 0.0686 & 2.0 & $\begin{array}{r}\text { Grams. } \\
3.50\end{array}$ & 0.0686 & 2.0 & $\begin{array}{r}\text { Grams. } \\
3.50\end{array}$ & 0.0686 & 2.0 \\
\hline \multicolumn{10}{|l|}{ Seeds: } \\
\hline 5 days.. & 2.12 & .0380 & 1.8 & 2.07 & .0313 & 1.5 & 2.07 & .0320 & 1.5 \\
\hline 7 days.. & 1.57 & .0405 & 2.6 & 1.41 & .0316 & 2.2 & 1.42 & .0418 & 2.9 \\
\hline 9 days.. & 1.21 & .0451 & 3.7 & .93 & .0450 & 4.8 & 1.01 & .0450 & 4.5 \\
\hline 12 days................ & .71 & .0420 & 5.9 & .56 & .0447 & 7.9 & .49 & .0423 & 8.6 \\
\hline 15 days.. & .60 & .0470 & 7.9 & .46 & .0413 & 6.9 & .50 & .0408 & 8.2 \\
\hline \multicolumn{10}{|l|}{ Axes: } \\
\hline 5 days..... & 1.01 & .0233 & 2.3 & .96 & .0205 & 2.1 & 1.14 & .0355 & 3.1 \\
\hline $\begin{array}{l}7 \text { days...... } \\
9 \text { days.... }\end{array}$ & 1.23 & .0330 & 2. & 1.23 & .0440 & 3. & 1.41 & .0422 & 3.0 \\
\hline 12 days..... & $\begin{array}{l}1.48 \\
1.33\end{array}$ & $\begin{array}{r}.0443 \\
.0397\end{array}$ & 3.0 & 1.55 & .0615 & 3.9 & 1.64 & .0593 & 3.6 \\
\hline 15 days... & 1.48 & .0450 & $\begin{array}{l}3.0 \\
3.0\end{array}$ & 1.08 & .0643 & $\ddot{3} . \overline{7}$ & 1.90 & .0070 & $\begin{array}{l}3.5 \\
3.7\end{array}$ \\
\hline \multicolumn{10}{|l|}{ Total plants: } \\
\hline 5 days... & 3.13 & .0613 & 2.0 & 3.03 & .0518 & 1.7 & 3.21 & .0675 & 2.1 \\
\hline 7 days.. & 2.80 & .0735 & 2.6 & 2.64 & .0756 & 2.9 & 2.83 & .0840 & 3.0 \\
\hline 9 days... & 2.69 & .0894 & 3.3 & 2.48 & .1065 & 4.3 & 2.65 & .1043 & 3.9 \\
\hline 12 days.. & 2.04 & .0817 & 4.0 & 2.23 & & & 2.39 & .1093 & 4.6 \\
\hline 15 days.. & 2.08 & .0920 & 4.4 & 2.17 & .1056 & 4.9 & 2.41 & .1117 & 4.6 \\
\hline
\end{tabular}




\section{FIBER.}

The fiber in 100 seeds amounts to 0.0785 gram. At the end of 15 days there is a decrease of fiber in the residual seed of about 6 per cent, practically the same conditions obtaining in the control as in culture media, as is shown in Tables 7 and 8 . There is, therefore, no apparent absorption of the nonembryo fiber from the seed by the plant in 15 days. On the other hand, the axes in 5 days formed twice as much fiber as was in the seed, and in 15 days the amount was from 5 to 7 times that in the seed, the fiber formation increasing steadily, as may be seen from the tables. There is a slightly greater amount of fiber found in the axes of plants grown in the nutrient solutions than in those in the water culture, owing to the greater growth which the seedlings made under the stimulus of the plant food. However, the per cent of fiber in the axes is approximately the same irrespective of the kind of solution in which the plants were grown, as shown in the tables. The fact that the sugars increased to such an extent only at last to disappear almost entirely (see p. 28), and that the pentosans also increased and then remained practically stationary (see p. 26), would seem to indicate that a large part of the sugar is finally converted into fibrous material, some of it possibly passing through the pentosan stage. According to Ravenna and Cereser, ${ }^{1}$ the simple sugars exert a great influence on the formation of pentosans, and, according to Calabresi, ${ }^{2}$ there is a very close, though not genetic, relation between the pentosans and cellulose.

\footnotetext{
1 Atti. R. Accad. Lincei, 1909, 18 [v]: 177.
}

${ }^{2}$ Stazioni sperimentali agrarie, italiane, 1906, 39:69. 
TABLE 7.-Dry weight and fiber of seeds, axes, and total plants when grown for 15 days in solutions containing a single nutrient.

\begin{tabular}{|c|c|c|c|c|c|c|c|c|c|}
\hline \multirow{3}{*}{ Parts of plant and age. } & \multicolumn{3}{|c|}{ Control solution. } & \multicolumn{3}{|c|}{ Potash solution. } & \multicolumn{3}{|c|}{ Phosphoric acid solution. } \\
\hline & \multirow{2}{*}{$\begin{array}{c}\text { Weight of } \\
100 .\end{array}$} & \multicolumn{2}{|c|}{ Fiber. } & \multirow{2}{*}{$\begin{array}{c}\text { Weight of } \\
100 .\end{array}$} & \multicolumn{2}{|c|}{ Fiber. } & \multirow{2}{*}{$\begin{array}{c}\text { Weight of } \\
100 .\end{array}$} & \multicolumn{2}{|c|}{ Fiber. } \\
\hline & & Grams. & $\begin{array}{c}\text { Per } \\
\text { cent. }\end{array}$ & & Grams. & $\begin{array}{l}\text { Per } \\
\text { cent. }\end{array}$ & & Grams. & $\begin{array}{c}\text { Per } \\
\text { cent. }\end{array}$ \\
\hline Original seed.......... & $\begin{array}{c}\text { Grams. } \\
3.50\end{array}$ & 0.0785 & 2.2 & $\begin{array}{c}\text { Grams. } \\
3.50\end{array}$ & 0.0785 & 2.2 & $\begin{array}{c}\text { Grams. } \\
3.50\end{array}$ & 0.0785 & 2.2 \\
\hline 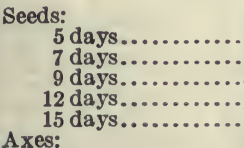 & $\begin{array}{r}1.876 \\
1.380 \\
.929 \\
.616 \\
.360\end{array}$ & $\begin{array}{l}.0885 \\
.0646 \\
.0745 \\
.0740 \\
.0732\end{array}$ & $\begin{array}{r}4.7 \\
4.7 \\
8.0 \\
12.0 \\
20.3\end{array}$ & $\begin{array}{r}1.966 \\
1.481 \\
1.040 \\
.698 \\
.384\end{array}$ & $\begin{array}{l}.0825 \\
.0700 \\
.0730 \\
.0835 \\
.0755\end{array}$ & $\begin{array}{r}4.2 \\
4.7 \\
7.0 \\
12.0 \\
19.7\end{array}$ & $\begin{array}{r}1.738 \\
1.291 \\
.796 \\
.488 \\
.359\end{array}$ & $\begin{array}{l}.0764 \\
.0740 \\
.0750 \\
.0755 \\
.0740\end{array}$ & $\begin{array}{r}4.4 \\
5.7 \\
9.4 \\
15.5 \\
20.7\end{array}$ \\
\hline 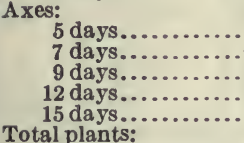 & $\begin{array}{l}1.126 \\
1.343 \\
1.540 \\
1.564 \\
1.480\end{array}$ & $\begin{array}{l}.1665 \\
.2380 \\
.3105 \\
.3460 \\
.4050\end{array}$ & $\begin{array}{l}14.7 \\
17.7 \\
20.2 \\
22.2 \\
27.4\end{array}$ & $\begin{array}{l}1.100 \\
1.424 \\
1.514 \\
1.729 \\
1.773\end{array}$ & $\begin{array}{l}.1525 \\
.2622 \\
.2900 \\
.3856 \\
.4740\end{array}$ & $\begin{array}{l}13.8 \\
18.5 \\
19.2 \\
22.3 \\
26.8\end{array}$ & $\begin{array}{l}1.195 \\
1.552 \\
1.948 \\
1.762 \\
1.873\end{array}$ & $\begin{array}{l}.0740 \\
.1776 \\
.2995 \\
.4100 \\
.4310 \\
.5072\end{array}$ & $\begin{array}{l}20.8 \\
11.4 \\
19.4 \\
21.0 \\
24.5 \\
27.1\end{array}$ \\
\hline 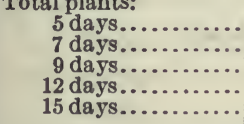 & $\begin{array}{l}3.002 \\
2.723 \\
2.469 \\
2.180 \\
1.840\end{array}$ & $\begin{array}{l}.2550 \\
.3026 \\
.3850 \\
.4200 \\
.4782\end{array}$ & $\begin{array}{r}8.5 \\
11.1 \\
15.6 \\
19.3 \\
26.0\end{array}$ & $\begin{array}{l}3.066 \\
2.905 \\
2.554 \\
2.427 \\
2.157\end{array}$ & $\begin{array}{l}.2350 \\
.3322 \\
.3630 \\
.4691 \\
.5495\end{array}$ & $\begin{array}{r}7.7 \\
11.4 \\
14.2 \\
19.3 \\
25.5\end{array}$ & $\begin{array}{l}2.933 \\
2.843 \\
2.744 \\
2.250 \\
2.232\end{array}$ & $\begin{array}{l}.2540 \\
.3735 \\
.4850 \\
.5065 \\
.5812\end{array}$ & $\begin{array}{r}8.7 \\
13.1 \\
17.7 \\
22.5 \\
26.0\end{array}$ \\
\hline \multirow{3}{*}{ Parts of plant and age. } & \multicolumn{3}{|c|}{ Control solution. } & \multicolumn{3}{|c|}{ Nitrate solution. } & \multicolumn{3}{|c|}{ Complete solution. } \\
\hline & \multirow{2}{*}{$\begin{array}{c}\text { Weight of } \\
100 .\end{array}$} & \multicolumn{2}{|c|}{ Fiber. } & \multirow{2}{*}{$\begin{array}{l}\text { Weight of } \\
100 .\end{array}$} & \multicolumn{2}{|c|}{ Fiber. } & & \multicolumn{2}{|c|}{ Fiber. } \\
\hline & & Grams. & $\begin{array}{c}\text { Per } \\
\text { cent. }\end{array}$ & & Grams. & $\begin{array}{l}\text { Per } \\
\text { cent. }\end{array}$ & 100. & Grams. & $\begin{array}{l}\text { Per } \\
\text { cent. }\end{array}$ \\
\hline Original seed.. & $\begin{array}{c}\text { Grams. } \\
3.50\end{array}$ & 0.0785 & 2.2 & $\begin{array}{c}\text { Grams. } \\
3.50\end{array}$ & 0.0785 & 2.2 & $\begin{array}{c}\text { Grams. } \\
3.50\end{array}$ & 0.0785 & 2.2 \\
\hline Seeds: & & & & & & & & & \\
\hline 5 days. & 2.121 & .0895 & 4.2 & 2.070 & .0874 & 4.2 & 2.074 & .0874 & 4. 2 \\
\hline & 1.568 & .0 & 5.5 & 1.409 & & & 1.422 & & 5.9 \\
\hline 9 days & 1.210 & .0880 & 7.3 & .934 & .0882 & 9.4 & 1.012 & .0760 & 7.6 \\
\hline 12 days & .714 & .0607 & 8.6 & .561 & .0660 & 11.8 & .490 & .0659 & 13.4 \\
\hline 15 days. & .596 & .0758 & 12.7 & .463 & .0678 & 11.4 & .498 & .0686 & 13.8 \\
\hline Axes: 5 days & 1010 & & & & & & & & \\
\hline 7 days. & $\begin{array}{l}1.010 \\
1.232\end{array}$ & $\begin{array}{r}.1565 \\
2303\end{array}$ & $\begin{array}{l}15 . \\
18 .\end{array}$ & .957 & .1395 & $\begin{array}{l}14.6 \\
16.8\end{array}$ & $\begin{array}{l}1.139 \\
1.415\end{array}$ & $\begin{array}{r}1830 \\
.2635\end{array}$ & $\begin{array}{l}16.1 \\
18.6\end{array}$ \\
\hline & 1.481 & .3192 & 21 & 1.552 & .3146 & 20 & 1.635 & .3670 & $\begin{array}{l}10.0 \\
22.4\end{array}$ \\
\hline 12 days & 1.330 & .3027 & 22.8 & 1.666 & .3819 & 22.9 & 1.900 & .4660 & 24.5 \\
\hline 15 days... & 1.481 & .3730 & 25.2 & 1.713 & .5030 & 29.4 & 1.909 & .4110 & 21.6 \\
\hline Total plants: & & & & & & & & & \\
\hline 7 days.. & $\begin{array}{l}3.131 \\
2.800\end{array}$ & .3113 & 11.1 & $\begin{array}{l}3.027 \\
2.639\end{array}$ & $\begin{array}{l}.2269 \\
.2952\end{array}$ & $\begin{array}{r}7.5 \\
11.2\end{array}$ & $\begin{array}{l}3.213 \\
2.837\end{array}$ & $\begin{array}{l}.2704 \\
.3471\end{array}$ & $\begin{array}{r}8.4 \\
12.2\end{array}$ \\
\hline & 2. 691 & .4072 & 15.1 & 2.486 & .4028 & 16.2 & 2. 647 & .4430 & 16.7 \\
\hline 12 days & 2. 044 & .3634 & 17.8 & 2. 227 & .4479 & 20.0 & 2.390 & .5319 & 22.3 \\
\hline 15 days.. & 2.077 & .4488 & 21.6 & 2.176 & .5708 & 26.2 & 2.407 & .4796 & 19.9 \\
\hline
\end{tabular}


TABLE 8.-Dry weight and fiber of seeds, axes, and total plants when grown for 15 days in different nutrient solutions.

\begin{tabular}{|c|c|c|c|c|c|c|}
\hline \multirow{3}{*}{ Parts of plants and age. } & \multicolumn{3}{|c|}{ Complete less potash. } & \multicolumn{3}{|c|}{ Complete less phosphoric acid. } \\
\hline & \multirow{2}{*}{$\begin{array}{l}\text { Weight of } \\
100 .\end{array}$} & \multicolumn{2}{|c|}{ Fiber. } & \multirow{2}{*}{$\begin{array}{c}\text { Weight of } \\
100 .\end{array}$} & \multicolumn{2}{|c|}{ Fiber. } \\
\hline & & Grams. & Per cent. & & Grams. & Per cent. \\
\hline Original seed. & $\begin{array}{r}\text { Grams. } \\
3.50\end{array}$ & 0.0785 & 2.2 & $\begin{array}{r}\text { Grams. } \\
3.50\end{array}$ & 0.0785 & 2. 2 \\
\hline 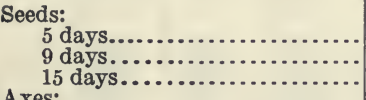 & $\begin{array}{r}1.650 \\
.766 \\
.377\end{array}$ & $\begin{array}{l}.0870 \\
.0760 \\
.0700\end{array}$ & $\begin{array}{r}5.3 \\
9.9 \\
18.6\end{array}$ & $\begin{array}{l}1.74 \\
.675 \\
.348\end{array}$ & $\begin{array}{l}.0840 \\
.0790 \\
.0780\end{array}$ & $\begin{array}{r}4.8 \\
11.7 \\
22.4\end{array}$ \\
\hline $\begin{array}{r}5 \text { days..... } \\
9 \text { days.... } \\
15 \text { days... }\end{array}$ & $\begin{array}{l}1.230 \\
1.740 \\
1.921\end{array}$ & $\begin{array}{l}.215 \\
.416 \\
.522\end{array}$ & $\begin{array}{l}17.5 \\
23.9 \\
27.2\end{array}$ & $\begin{array}{l}1.177 \\
1.833 \\
2.153\end{array}$ & $\begin{array}{l}.198 \\
.433 \\
.648\end{array}$ & $\begin{array}{l}16.8 \\
23.6 \\
30.1\end{array}$ \\
\hline $\begin{array}{l}5 \text { days.... } \\
9 \text { days... } \\
15 \text { days.. }\end{array}$ & $\begin{array}{l}2.880 \\
2.506 \\
2.298\end{array}$ & $\begin{array}{l}.3020 \\
.4920 \\
.5920\end{array}$ & $\begin{array}{l}10.5 \\
19.6 \\
25.8\end{array}$ & $\begin{array}{l}2.917 \\
2.508 \\
2.501\end{array}$ & $\begin{array}{l}.2820 \\
.5120 \\
.7260\end{array}$ & $\begin{array}{r}9.7 \\
20.4 \\
29.0\end{array}$ \\
\hline \multirow{3}{*}{ Parts of plants and age. } & \multicolumn{3}{|c|}{ Complete less nitrate. } & \multicolumn{3}{|c|}{ Complete solution. } \\
\hline & \multirow{2}{*}{$\begin{array}{c}\text { Weight of } \\
100 .\end{array}$} & \multicolumn{2}{|c|}{ Fiber. } & \multirow{2}{*}{$\begin{array}{c}\text { Weight of } \\
100 .\end{array}$} & \multicolumn{2}{|c|}{ Fiber. } \\
\hline & & Grams. & Per cent. & & Grams. & Per cent. \\
\hline Original seed.. & $\begin{array}{r}\text { Grams. } \\
3.50\end{array}$ & 0.0785 & 2.2 & $\begin{array}{r}\text { Grams. } \\
3.50\end{array}$ & 0.0785 & 2.2 \\
\hline 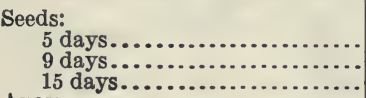 & $\begin{array}{r}1.710 \\
.790 \\
.375\end{array}$ & $\begin{array}{l}.0790 \\
.0800 \\
.0750\end{array}$ & $\begin{array}{r}4.6 \\
10.1 \\
20.0\end{array}$ & $\begin{array}{r}1.643 \\
.621 \\
.291\end{array}$ & $\begin{array}{l}.0880 \\
.0830 \\
.0700\end{array}$ & $\begin{array}{r}5.4 \\
13.0 \\
24.0\end{array}$ \\
\hline 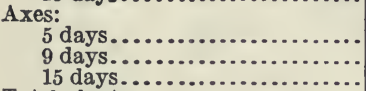 & $\begin{array}{l}1.212 \\
1.977 \\
2.066\end{array}$ & $\begin{array}{l}.199 \\
.368 \\
.589\end{array}$ & $\begin{array}{l}16.4 \\
18.6 \\
28.5\end{array}$ & $\begin{array}{l}1.220 \\
1.945 \\
2.142\end{array}$ & $\begin{array}{l}.2320 \\
.3680 \\
.6070\end{array}$ & $\begin{array}{l}19.0 \\
18.9 \\
28.3\end{array}$ \\
\hline $\begin{array}{l}\text { Total plants: } \\
5 \text { days.... } \\
9 \text { days..... } \\
15 \text { days... }\end{array}$ & $\begin{array}{l}2.922 \\
2.767 \\
2.441\end{array}$ & $\begin{array}{l}.2780 \\
.4480 \\
.6640\end{array}$ & $\begin{array}{r}9.5 \\
16.2 \\
27.2\end{array}$ & $\begin{array}{l}2.863 \\
2.566 \\
2.433\end{array}$ & $\begin{array}{l}.3200 \\
.4510 \\
.6770\end{array}$ & $\begin{array}{l}11.2 \\
17.5 \\
27.8\end{array}$ \\
\hline
\end{tabular}

TABLE 9.-Per cent of fiber in axes based on amount in original seed.

\begin{tabular}{|c|c|c|c|c|c|c|c|c|c|c|c|}
\hline \multirow{2}{*}{ Age. } & \multirow{2}{*}{$\begin{array}{c}\text { Control } \\
\text { solu- } \\
\text { tion. }\end{array}$} & \multirow{2}{*}{$\begin{array}{l}\text { Potash } \\
\text {. solu- } \\
\text { tion. }\end{array}$} & \multirow{2}{*}{$\begin{array}{l}\text { Phos- } \\
\text { phoric } \\
\text { acid so- } \\
\text { lution. }\end{array}$} & \multirow{2}{*}{$\begin{array}{l}\text { Control } \\
\text { solu- } \\
\text { tion. }\end{array}$} & \multirow{2}{*}{$\begin{array}{l}\text { Nitro- } \\
\text { gen so- } \\
\text { lution. }\end{array}$} & \multirow{2}{*}{$\begin{array}{l}\text { Com- } \\
\text { plete } \\
\text { nutri- } \\
\text { ent so- } \\
\text { lution. }\end{array}$} & \multirow{2}{*}{$\begin{array}{c}\text { Tap } \\
\text { water. }\end{array}$} & \multicolumn{3}{|c|}{$\begin{array}{l}\text { Complete nutrient } \\
\text { solution- }\end{array}$} & \multirow{2}{*}{$\begin{array}{l}\text { Com- } \\
\text { plete } \\
\text { nutri- } \\
\text { ent so- } \\
\text { lution. }\end{array}$} \\
\hline & & & & & & & & $\begin{array}{c}\text { Less } \\
\text { potash. }\end{array}$ & $\begin{array}{l}\text { Less } \\
\text { phos- } \\
\text { phoric } \\
\text { acid. }\end{array}$ & $\begin{array}{l}\text { Less } \\
\text { nitro- } \\
\text { gen. }\end{array}$ & \\
\hline Plants: & & & & & & & & & & - & \\
\hline 5 days. . & 210 & 195 & 225 & 200 & 180 & 230 & 210 & 275 & 255 & 255 & 295 \\
\hline $\begin{array}{l}7 \text { days.. } \\
9 \text { days.. }\end{array}$ & $\begin{array}{l}300 \\
395\end{array}$ & $\begin{array}{l}330 \\
370\end{array}$ & $\begin{array}{l}380 \\
520\end{array}$ & $\begin{array}{l}295 \\
400\end{array}$ & $\begin{array}{l}260 \\
400\end{array}$ & $\begin{array}{l}335 \\
470\end{array}$ & $\begin{array}{l}300 \\
400\end{array}$ & 530 & 550 & 470 & 470 \\
\hline 12 days. & 440 & 490 & 550 & 385 & 485 & 595 & 520 & & & & \\
\hline $\begin{array}{l}15 \text { days. } \\
\text { Seeds: }\end{array}$ & 510 & 605 & 645 & 480 & 640 & 1595 & 570 & 665 & 825 & 735 & 710 \\
\hline $\begin{array}{l}5 \text { days.. } \\
7 \text { days.. }\end{array}$ & $\begin{array}{r}113 \\
82\end{array}$ & $\begin{array}{r}-105 \\
89\end{array}$ & $\begin{array}{l}97 \\
94\end{array}$ & $\begin{array}{l}114 \\
103\end{array}$ & $\begin{array}{l}111 \\
112\end{array}$ & $\begin{array}{l}111 \\
106\end{array}$ & $\begin{array}{r}94 \\
102\end{array}$ & 111 & 107 & 101 & 112 \\
\hline 9 days.. & 95 & 93 & 96 & 112 & 112 & 97 & 87 & 97 & 101 & 102 & 106 \\
\hline 12 days. & 94 & 106 & 95 & 77 & 84 & 84 & 95 & $\ddot{80}$ & ....... & 06 & $-\cdots \cdot \theta^{\prime}$ \\
\hline 15 days & 93 & 96 & 94 & 97 & 86 & 87 & 95 & 89 & 99 & 96 & 89 \\
\hline
\end{tabular}


TABLE 10.-Dry weight of seeds and axes and the fiber found in same when grown for 14 days in tap water.

\begin{tabular}{|c|c|c|c|c|c|c|c|c|c|}
\hline \multirow{3}{*}{ Age. } & \multicolumn{3}{|c|}{ Residual seeds. } & \multicolumn{3}{|c|}{ Axes. } & \multicolumn{3}{|c|}{ Total plant. } \\
\hline & \multirow{2}{*}{$\begin{array}{l}\text { Weight } \\
\text { of } 100 .\end{array}$} & \multicolumn{2}{|c|}{ Fiber. } & \multirow{2}{*}{$\begin{array}{l}\text { Weight } \\
\text { of } 100 .\end{array}$} & \multicolumn{2}{|c|}{ Fiber. } & \multirow{2}{*}{$\begin{array}{l}\text { Weight } \\
\text { of } 100 .\end{array}$} & \multicolumn{2}{|c|}{ Fiber. } \\
\hline & & Grams & $\begin{array}{c}\text { Per } \\
\text { cent. }\end{array}$ & & Grams. & $\begin{array}{c}\text { Per } \\
\text { cent. }\end{array}$ & & Grams. & $\begin{array}{c}\text { Per } \\
\text { cent. }\end{array}$ \\
\hline Original seeds.. & $\begin{array}{c}\text { Grams. } \\
3.50\end{array}$ & 0.0785 & 2.2 & 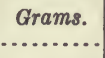 & & & Grams. & & \\
\hline 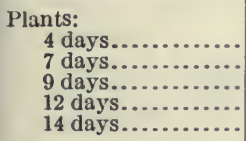 & $\begin{array}{r}2.408 \\
1.554 \\
.914 \\
.642 \\
.519\end{array}$ & $\begin{array}{l}.0740 \\
.0801 \\
.0685 \\
.0744 \\
.0740\end{array}$ & $\begin{array}{r}3.1 \\
5.2 \\
7.5 \\
11.6 \\
14.3\end{array}$ & $\begin{array}{l}0.574 \\
1.389 \\
1.566 \\
1.816 \\
1.825\end{array}$ & $\begin{array}{r}0.0928 \\
.2410 \\
.3164 \\
.4100 \\
.4460\end{array}$ & $\begin{array}{l}16.2 \\
17.4 \\
20.2 \\
22.6 \\
24.4\end{array}$ & $\begin{array}{l}2.982 \\
2.943 \\
2.480 \\
2.458 \\
2.344\end{array}$ & $\begin{array}{l}0.1668 \\
.3211 \\
.3849 \\
.4844 \\
.5200\end{array}$ & $\begin{array}{r}5.6 \\
10.9 \\
15.5 \\
19.7 \\
22.2\end{array}$ \\
\hline
\end{tabular}

PENTOSANS.

The amount of pentosans in 100 original seeds is 0.2561 gram. There is a gradual decrease of pentosans in the seeds throughout the 15 days, and at the end of that period only from 40 to 50 per cent of the original amount of pentosans is present. This change takes place under all conditions of growth as seen from Tables 11 and 12 . In the axes, however, the increase of this substance is quite rapid up to about the ninth day. On the fifth day they contain about one-half as much as did the original seeds, and on the ninth day an amount equal to that of the original seed is present. After that date there is a slight but irregular increase, due possibly to the conversion of the pentosans into fiber. The pentosans are supposed to be produced from sugars and to serve as reserve material. As in the case of the fat, at the end of the fifteenth day there is a somewhat larger amount of pentosans in the axes of plants grown in the nutrient solutions than in the control. According to De Chalmot (ibid.) nitrogen fertilizers cause an increase in the pentosan content of plants, especially in the stems. The results here obtained do not indicate that nitrates form any larger amount of pentosans in the axes of seedlings than is formed by potash or phosphoric acid, the differences between the amounts found in the axes of plants grown in different mediums being too small to warrant any definite conclusions.

In fact, while a somewhat larger amount of pentosans is found in the axes of seedlings grown in the various nutrient solutions than in those of the control (see Table 11) this is probably due to the larger growth made by the plants grown in the presence of plant food. The actual per cent of pentosans based on the dry matter in the axes is approximately the same in each case, i. e., it varies only within the limit of error. From the tables it would seem that from 40 to 50 per cent of the original pentosans of the seed remain therein at the end of 15 days. The other 50 to 60 per cent have been utilized 
for the production of pentosans in the axes. Besides this amount, however, which has been translocated to the plant, there has been produced in the axes, through assimilation, an amount equal to 50 per cent of the original amount in the seed, produced in all probability at the expense of the sugars.

TABLE 11.-Pentosans found in residual seeds and axes when grown in solutions containing one nutrient.

\begin{tabular}{|c|c|c|c|c|c|c|c|c|c|}
\hline \multirow{3}{*}{$\begin{array}{c}\text { Parts of plant and } \\
\text { age. }\end{array}$} & \multicolumn{3}{|c|}{ Control solution. } & \multicolumn{3}{|c|}{ Potash solution. } & \multicolumn{3}{|c|}{ Phosphoricacid solution. } \\
\hline & \multirow{2}{*}{$\begin{array}{l}\text { Weight } \\
\text { of } 100 \text {. }\end{array}$} & \multicolumn{2}{|c|}{ Pentosans. } & \multirow{2}{*}{$\begin{array}{l}\text { Weight } \\
\text { of } 100 \text {. }\end{array}$} & \multicolumn{2}{|c|}{ Pentosans. } & \multirow{2}{*}{$\begin{array}{l}\text { Weight } \\
\text { of } 100 .\end{array}$} & \multicolumn{2}{|c|}{ Pentosans. } \\
\hline & & Grams. & $\begin{array}{l}\text { Per } \\
\text { cent. }\end{array}$ & & Grams. & $\begin{array}{l}\text { Per } \\
\text { cent. }\end{array}$ & & Grams. & $\begin{array}{l}\text { Per } \\
\text { cent. }\end{array}$ \\
\hline Original seed & $\begin{array}{l}\text { Grams. } \\
3.50\end{array}$ & 0.2561 & 7.3 & $\begin{array}{c}\text { Grams. } \\
3.50\end{array}$ & 0.2561 & 7.3 & $\begin{array}{r}\text { Grams. } \\
3.50\end{array}$ & 0.2561 & 7.3 \\
\hline $\begin{array}{l}\text { Seeds: } \\
5 \text { days. } \\
7 \text { days. } \\
9 \text { days. } \\
12 \text { days. } \\
15 \text { days. }\end{array}$ & $\begin{array}{r}1.876 \\
1.380 \\
.929 \\
.616 \\
.360\end{array}$ & $\begin{array}{l}.2054 \\
.1853 \\
.1782 \\
.1297 \\
.1120\end{array}$ & $\begin{array}{l}10.9 \\
13.4 \\
19.2 \\
21.1 \\
31.1\end{array}$ & $\begin{array}{r}1.966 \\
1.481 \\
1.040 \\
.698 \\
.384\end{array}$ & $\begin{array}{l}.2176 \\
.2054 \\
.1853 \\
.1660 \\
.1280\end{array}$ & $\begin{array}{l}11.1 \\
13.9 \\
17.8 \\
23.8 \\
33.3\end{array}$ & $\begin{array}{r}1.738 \\
1.291 \\
.796 \\
.488 \\
.359\end{array}$ & $\begin{array}{l}.2203 \\
.1887 \\
.1738 \\
.1395 \\
.1138\end{array}$ & $\begin{array}{l}12.7 \\
14.7 \\
21.9 \\
28.7 \\
31.4\end{array}$ \\
\hline $\begin{array}{r}\text { Axes: } \\
5 \text { days } \\
7 \text { days } \\
9 \text { days } \\
12 \text { days } \\
15 \text { days } \\
\text { Total plant }\end{array}$ & $\begin{array}{l}1.126 \\
1.343 \\
1.540 \\
1.564 \\
1.480\end{array}$ & $\begin{array}{l}.1377 \\
.1729 \\
.2526 \\
.2755 \\
.2596\end{array}$ & $\begin{array}{l}12.3 \\
12.9 \\
16.4 \\
17.8 \\
17.6\end{array}$ & $\begin{array}{l}1.100 \\
1.424 \\
1.514 \\
1.729 \\
1.773\end{array}$ & $\begin{array}{l}.1315 \\
.1896 \\
.2964 \\
.2578 \\
.2789\end{array}$ & $\begin{array}{l}11.9 \\
13.4 \\
19.6 \\
14.9 \\
15.8\end{array}$ & $\begin{array}{l}1.195 \\
1.552 \\
1.948 \\
1.762 \\
1.873\end{array}$ & $\begin{array}{r}.1306 \\
.2168 \\
1.4764 \\
.2930 \\
.3021\end{array}$ & $\begin{array}{l}11.0 \\
14.0 \\
24.4 \\
16.6 \\
16.1\end{array}$ \\
\hline $\begin{array}{r}5 \text { days.. } \\
7 \text { days.. } \\
9 \text { days.. } \\
12 \text { days.. } \\
15 \text { days.. }\end{array}$ & $\begin{array}{l}3.002 \\
2.723 \\
2.469 \\
2.180 \\
1.840\end{array}$ & $\begin{array}{l}.3431 \\
.3582 \\
.4308 \\
.4052 \\
.3716\end{array}$ & $\begin{array}{l}11.4 \\
13.2 \\
17.4 \\
18.6 \\
20.2\end{array}$ & $\begin{array}{l}3.066 \\
2.905 \\
2.554 \\
2.427 \\
2.157\end{array}$ & $\begin{array}{l}.3491 \\
.3950 \\
.4817 \\
.4238 \\
.4069\end{array}$ & $\begin{array}{l}11.4 \\
13.6 \\
18.9 \\
17.5 \\
18.9\end{array}$ & $\begin{array}{l}2.933 \\
2.843 \\
2.744 \\
2.250 \\
2.132\end{array}$ & $\begin{array}{r}.3509 \\
.4055 \\
1.6502 \\
.4325 \\
.4159\end{array}$ & $\begin{array}{l}12.0 \\
14.3 \\
23.7 \\
19.2 \\
19.5\end{array}$ \\
\hline \multirow{3}{*}{$\begin{array}{l}\text { Parts of plant and } \\
\text { age. }\end{array}$} & \multicolumn{3}{|c|}{ Control solution. } & \multicolumn{3}{|c|}{ Nitrate solution. } & \multicolumn{3}{|c|}{ Complete solution. } \\
\hline & \multirow{2}{*}{$\begin{array}{l}\text { Weight } \\
\text { of } 100 .\end{array}$} & \multicolumn{2}{|c|}{ Pentosans. } & \multirow{2}{*}{$\begin{array}{l}\text { Weight } \\
\text { of } 100 .\end{array}$} & \multicolumn{2}{|c|}{ Pentosans. } & \multirow{2}{*}{$\begin{array}{l}\text { Weight } \\
\text { of } 100 .\end{array}$} & \multicolumn{2}{|c|}{ Pentosans. } \\
\hline & & Grams. & $\begin{array}{l}\text { Per } \\
\text { cent. }\end{array}$ & & Grams. & $\begin{array}{l}\text { Per } \\
\text { cent. }\end{array}$ & & Grams. & $\begin{array}{c}\text { Per } \\
\text { cent. }\end{array}$ \\
\hline Original see & $\begin{array}{l}\text { Grams. } \\
\quad 3.50\end{array}$ & 0.2561 & 7.3 & $\begin{array}{r}\text { Grams. } \\
3.50\end{array}$ & 0.2561 & 7.3 & $\begin{array}{l}\text { Grams. } \\
3.50\end{array}$ & 0.2561 & 7.3 \\
\hline $\begin{array}{l}\text { Seeds: } \\
5 \text { days.. } \\
7 \text { days.. } \\
9 \text { days. } \\
12 \text { days.. } \\
15 \text { days.. }\end{array}$ & $\begin{array}{r}2.121 \\
1.568 \\
1.210 \\
.714 \\
.596\end{array}$ & $\begin{array}{l}.2124 \\
.2124 \\
.1922 \\
.1738 \\
.1369\end{array}$ & $\begin{array}{l}10.0 \\
13.5 \\
15.9 \\
24.3 \\
23.0\end{array}$ & $\begin{array}{r}2.070 \\
1.409 \\
.934 \\
.561 \\
.463\end{array}$ & $\begin{array}{l}.2185 \\
.1983 \\
.1844 \\
.1430 \\
.1103\end{array}$ & $\begin{array}{l}10.5 \\
14.1 \\
19.8 \\
25.5 \\
18.5\end{array}$ & $\begin{array}{r}2.074 \\
1.422 \\
1.012 \\
.490 \\
.498\end{array}$ & $\begin{array}{l}.2256 \\
.2019 \\
.1808 \\
.1598 \\
.1192\end{array}$ & $\begin{array}{l}10.9 \\
14.2 \\
17.9 \\
32.6 \\
23.9\end{array}$ \\
\hline $\begin{array}{r}\text { Axes: } \\
5 \mathrm{da} \\
7 \mathrm{da} \\
9 \mathrm{da} \\
12 \mathrm{da} \\
15 \mathrm{da} \\
\text { Total pla }\end{array}$ & $\begin{array}{l}1.010 \\
1.232 \\
1.481 \\
1.330 \\
1.481\end{array}$ & $\begin{array}{l}.1201 \\
.1747 \\
.2046 \\
.2473 \\
.2300\end{array}$ & $\begin{array}{l}11.9 \\
14.2 \\
13.8 \\
18.6 \\
15.5\end{array}$ & $\begin{array}{r}.957 \\
1.230 \\
1.552 \\
1.666 \\
1.713\end{array}$ & $\begin{array}{l}.1103 \\
.1747 \\
.2435 \\
.3090 \\
.2631\end{array}$ & $\begin{array}{l}11.5 \\
14.2 \\
15.7 \\
18.5 \\
15.4\end{array}$ & $\begin{array}{l}1.139 \\
1.415 \\
1.635 \\
1.900 \\
1.909\end{array}$ & $\begin{array}{l}.1395 \\
.1957 \\
.2429 \\
.2499 \\
.2693\end{array}$ & $\begin{array}{l}12.2 \\
13.8 \\
14.9 \\
13.2 \\
14.2\end{array}$ \\
\hline $\begin{array}{r}\text { Total plants: } \\
5 \text { days.. } \\
7 \text { days.. } \\
9 \text { days.. } \\
12 \text { days.. } \\
15 \text { days.. }\end{array}$ & $\begin{array}{l}3.131 \\
2.800 \\
2.691 \\
2.044 \\
2.077\end{array}$ & $\begin{array}{l}.3325 \\
.3871 \\
.3968 \\
.4211 \\
.3669\end{array}$ & $\begin{array}{l}10.6 \\
13.8 \\
14.7 \\
20.6 \\
17.7\end{array}$ & $\begin{array}{l}3.027 \\
2.639 \\
2.486 \\
2.227 \\
2.176\end{array}$ & $\begin{array}{l}.3288 \\
.3730 \\
.4279 \\
.4520 \\
.3734\end{array}$ & $\begin{array}{l}10.9 \\
14.1 \\
17.2 \\
20.3 \\
17.2\end{array}$ & $\begin{array}{l}3.213 \\
2.837 \\
2.647 \\
2.390 \\
2.407\end{array}$ & $\begin{array}{l}.3651 \\
.3976 \\
.4237 \\
.4097 \\
.3885\end{array}$ & $\begin{array}{l}11.4 \\
14.0 \\
16.0 \\
17.1 \\
16.9\end{array}$ \\
\hline
\end{tabular}

1 Probable error; no sample for check analyses. 
TABLE 12.-Pentosans found in seeds and axes when grown in solutions lacking one nutrient.

\begin{tabular}{|c|c|c|c|c|c|c|c|c|c|c|c|c|}
\hline \multirow{3}{*}{$\begin{array}{c}\text { Parts of } \\
\text { plant and } \\
\text { age. }\end{array}$} & \multicolumn{3}{|c|}{ Complete less nitrate. } & \multicolumn{3}{|c|}{ Complete less potash. } & \multicolumn{3}{|c|}{$\begin{array}{l}\text { Complete less phos- } \\
\text { phorle acld. }\end{array}$} & \multicolumn{3}{|c|}{ Complete solution. } \\
\hline & \multirow{2}{*}{$\begin{array}{l}\text { Weight } \\
\text { of } 100 \text {. }\end{array}$} & \multicolumn{2}{|c|}{ Pentosans. } & \multirow{2}{*}{$\begin{array}{l}\text { Welght } \\
\text { of } 100 \text {. }\end{array}$} & \multicolumn{2}{|c|}{ Pentosans. } & \multirow{2}{*}{$\begin{array}{l}\text { Welght } \\
\text { of } 100 .\end{array}$} & \multicolumn{2}{|c|}{ Pentosans. } & \multirow{2}{*}{$\begin{array}{l}\text { Welght } \\
\text { of } 100 .\end{array}$} & \multicolumn{2}{|c|}{ Pentosans. } \\
\hline & & Grams. & $\begin{array}{l}\text { Per } \\
\text { cent. }\end{array}$ & & Grams. & $\begin{array}{l}\text { Per } \\
\text { cent. }\end{array}$ & & Grams. & $\begin{array}{l}\text { Per } \\
\text { cent. }\end{array}$ & & Grams. & $\begin{array}{c}\text { Per } \\
\text { cent. }\end{array}$ \\
\hline $\begin{array}{r}\text { Orlg In a } 1 \\
\text { seed....... }\end{array}$ & $\begin{array}{c}\text { Grams. } \\
3.50\end{array}$ & 0.256 & 7.3 & $\begin{array}{c}\text { Grams. } \\
3.50\end{array}$ & 0.256 & 7.3 & $\begin{array}{c}\text { Grams. } \\
3.50\end{array}$ & 0.256 & 7.3 & $\begin{array}{c}\text { Grams. } \\
\text { 3. } 50\end{array}$ & 0.256 & 7.3 \\
\hline $\begin{array}{l}\text { Seeds: } \\
5 \text { days. } \\
9 \text { days. } \\
15 \text { days. } \\
22 \text { days. }\end{array}$ & $\begin{array}{r}1.710 \\
.790 \\
.375 \\
.311\end{array}$ & $\begin{array}{l}.216 \\
.183 \\
.101 \\
.081\end{array}$ & $\begin{array}{l}12.6 \\
23.2 \\
27.0 \\
26.0\end{array}$ & $\begin{array}{r}1.650 \\
.766 \\
.377 \\
.338\end{array}$ & $\begin{array}{l}.216 \\
.166 \\
.111 \\
.088\end{array}$ & $\begin{array}{l}13.1 \\
21.7 \\
29.4 \\
26.0\end{array}$ & $\begin{array}{r}1.740 \\
.675 \\
.348 \\
\ldots \ldots\end{array}$ & $\begin{array}{l}.203 \\
.179 \\
.112 \\
\ldots \ldots\end{array}$ & $\begin{array}{c}11.7 \\
26.5 \\
32.2 \\
\cdots \cdots\end{array}$ & $\begin{array}{r}1.643 \\
.621 \\
.291 \\
.328\end{array}$ & $\begin{array}{l}.210 \\
.158 \\
.095 \\
.091\end{array}$ & $\begin{array}{l}12.8 \\
25.0 \\
33.0 \\
30.0\end{array}$ \\
\hline $\begin{array}{l}\text { Axes: } \\
5 \text { days. } \\
9 \text { days. } \\
15 \text { days. } \\
22 \text { days. } \\
\text { Total plants: }\end{array}$ & $\begin{array}{l}1.212 \\
1.977 \\
2.066 \\
1.880\end{array}$ & $\begin{array}{r}.160 \\
.303 \\
.331 \\
.322\end{array}$ & $\begin{array}{l}13.2 \\
15.3 \\
16.0 \\
17.1\end{array}$ & $\begin{array}{l}1.230 \\
1.740 \\
1.921 \\
1.755\end{array}$ & $\begin{array}{l}.127 \\
.270 \\
.312 \\
.331\end{array}$ & $\begin{array}{l}10.3 \\
15.5 \\
16.2 \\
18.9\end{array}$ & $\begin{array}{l}1.177 \\
1.833 \\
2.153\end{array}$ & $\begin{array}{l}.147 \\
.269 \\
.368 \\
\ldots \ldots\end{array}$ & $\begin{array}{l}12.5 \\
14.7 \\
17.1 \\
\cdots \cdots\end{array}$ & $\begin{array}{l}1.220 \\
1.945 \\
2.142 \\
1.750\end{array}$ & $\begin{array}{l}.154 \\
.314 \\
.330 \\
.323\end{array}$ & $\begin{array}{l}12.6 \\
16.1 \\
15.4 \\
18.5\end{array}$ \\
\hline $\begin{array}{r}\text { Total plants: } \\
5 \text { days. } \\
9 \text { days. } \\
15 \text { days. } \\
22 \text { days. }\end{array}$ & $\begin{array}{l}2.922 \\
2.767 \\
2.441 \\
2.191\end{array}$ & $\begin{array}{l}.376 \\
.486 \\
.432 \\
.403\end{array}$ & $\begin{array}{l}12.9 \\
17.6 \\
17.7 \\
18.4\end{array}$ & $\begin{array}{l}2.880 \\
2.506 \\
2.298 \\
2.093\end{array}$ & $\begin{array}{l}.343 . \\
.436 \\
.423 \\
.419\end{array}$ & $\begin{array}{l}11.9 \\
17.4 \\
18.4 \\
20.0\end{array}$ & $\begin{array}{l}2.917 \\
2.508 \\
2.501\end{array}$ & $\begin{array}{l}.350 \\
.448 \\
.480 \\
\ldots \ldots\end{array}$ & \begin{tabular}{c|}
12.0 \\
17.9 \\
19.2 \\
$\cdots \cdots$
\end{tabular} & $\begin{array}{r}2.863 \\
2.566 \\
2.433 \\
.2 .078\end{array}$ & $\begin{array}{l}.364 \\
.472 \\
.425 \\
.414\end{array}$ & $\begin{array}{l}12.7 \\
18.4 \\
17.5 \\
19.9\end{array}$ \\
\hline
\end{tabular}

TABLE 13.-Percentage of pentosans in axes and seeds based on original amount in seed.

\begin{tabular}{|c|c|c|c|c|c|c|c|c|c|c|c|}
\hline \multirow{2}{*}{$\begin{array}{c}\text { Parts of } \\
\text { plant } \\
\text { and age. }\end{array}$} & \multirow{2}{*}{$\begin{array}{l}\text { Control } \\
\text { solu- } \\
\text { tion. }\end{array}$} & \multirow{2}{*}{$\begin{array}{l}\text { Potash } \\
\text { solu- } \\
\text { tion. }\end{array}$} & \multirow{2}{*}{$\begin{array}{l}\text { Phos- } \\
\text { phoric } \\
\text { acld } \\
\text { solu- } \\
\text { tlon. }\end{array}$} & \multirow{2}{*}{$\begin{array}{l}\text { Control } \\
\text { solu- } \\
\text { tlon. }\end{array}$} & \multirow{2}{*}{$\begin{array}{l}\text { Nitro- } \\
\text { gen } \\
\text { solu- } \\
\text { tlon. }\end{array}$} & \multirow{2}{*}{$\begin{array}{l}\text { Com- } \\
\text { plete } \\
\text { solu- } \\
\text { tlon. }\end{array}$} & \multirow{2}{*}{$\begin{array}{c}\text { Tap } \\
\text { water. }\end{array}$} & \multicolumn{3}{|c|}{ Complete solution less- } & \multirow{2}{*}{$\begin{array}{l}\text { Com- } \\
\text { plete } \\
\text { solu- } \\
\text { tlon. }\end{array}$} \\
\hline & & & & & & & & Potash. & $\begin{array}{c}\text { Phos- } \\
\text { phorus. }\end{array}$ & $\begin{array}{l}\text { Nitro- } \\
\text { gen. }\end{array}$ & \\
\hline \multicolumn{12}{|l|}{ Axes: } \\
\hline $\begin{array}{l}5 \text { days. } \\
7 \text { days. }\end{array}$ & $\begin{array}{l}53 \\
67\end{array}$ & $\begin{array}{l}51 \\
74\end{array}$ & $\begin{array}{l}51 \\
84\end{array}$ & $\begin{array}{l}47 \\
68\end{array}$ & $\begin{array}{l}43 \\
68\end{array}$ & $\begin{array}{l}54 \\
76\end{array}$ & $\begin{array}{l}41 \\
60\end{array}$ & 62 & 50 & 58 & 60 \\
\hline 9 days. & 100 & 115 & & 80 & 95 & 95 & 85 & 118 & $\dddot{105}$ & $\ddot{105}$ & $\dddot{122}$ \\
\hline 12 days. & 107 & 100 & 114 & 96 & 121 & 97 & 105 & & & & \\
\hline 15 days. & 101 & 109 & 118 & 90 & 102 & 105 & 120 & 129 & 122 & 143 & 129 \\
\hline $\begin{array}{l}\text { Seeds: } \\
5 \text { days. }\end{array}$ & 80 & 85 & 86 & 83 & 85 & 88 & 86 & 84 & $\begin{array}{r}129 \\
84\end{array}$ & 80 & 82 \\
\hline 7 days. & $\begin{array}{l}72 \\
70\end{array}$ & $\begin{array}{l}80 \\
72\end{array}$ & $\begin{array}{l}74 \\
68\end{array}$ & $\begin{array}{l}83 \\
75\end{array}$ & $\begin{array}{l}77 \\
72\end{array}$ & $\begin{array}{l}79 \\
71\end{array}$ & $\begin{array}{l}80 \\
68\end{array}$ & 72 & $\because 65$ & 70 & $\ddot{62}$ \\
\hline 12 days. & 51 & 65 & 55 & 68 & 56 & 63 & 58 & .... & & & $\cdots$ \\
\hline 15 days. & 44 & 50 & 45 & 53 & 43 & 46 & 45 & 39 & 43 & 44 & 37 \\
\hline
\end{tabular}




\section{REDUCING SUGAR AND SUCROSE.}

Tables 14 and 15 show how great have been the changes in both the reducing sugars and the hydrolyzable sugar during the 15 days of the life of the seedling.

TABLE 14.-Reducing sugars (as dextrose) in residual seeds and axes when grown for 15 days in solutions containing one nutrient.

\begin{tabular}{|c|c|c|c|c|}
\hline Parts of plant and age. & $\begin{array}{l}\text { Control } \\
\text { solution. }\end{array}$ & $\begin{array}{l}\text { Nitrate } \\
\text { solution. }\end{array}$ & $\begin{array}{c}\text { Potash } \\
\text { solution. }\end{array}$ & $\begin{array}{l}\text { Phos- } \\
\text { phoric } \\
\text { acid solu- } \\
\text { tion. }\end{array}$ \\
\hline Original seed... & Mg. & $M g$. & $M g$. & ${ }_{0}$ \\
\hline $\begin{aligned} & \text { Seeds: } \\
& 3 \\
& 3 \\
& 5 \\
& \text { days. }\end{aligned}$ & $\begin{array}{r}98.6 \\
192.4 \\
193.8 \\
\text { Lost. } \\
81.0 \\
22.6\end{array}$ & $\begin{array}{r}117.0 \\
173.3 \\
115.6 \\
72.0 \\
24.5 \\
8.3\end{array}$ & $\begin{array}{r}122.9 \\
160.5 \\
134.4 \\
91.0 \\
46.7 \\
21.7\end{array}$ & $\begin{array}{r}112.5 \\
157.0 \\
104.4 \\
80.5 \\
40.3 \\
12.8\end{array}$ \\
\hline 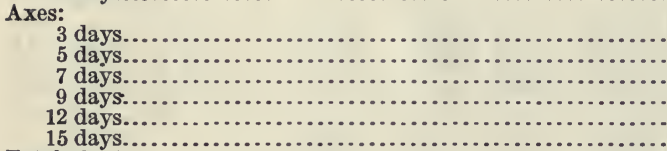 & $\begin{array}{r}148.0 \\
253.7 \\
267.9 \\
262.3 \\
180.1 \\
91.3\end{array}$ & $\begin{array}{l}136.8 \\
267.9 \\
265.7 \\
324.8 \\
157.0 \\
105.0\end{array}$ & $\begin{array}{r}124.8 \\
208.8 \\
228.3 \\
244.7 \\
118.2 \\
79.2\end{array}$ & $\begin{array}{l}130.3 \\
257.4 \\
246.4 \\
298.8 \\
167.4 \\
121.0\end{array}$ \\
\hline 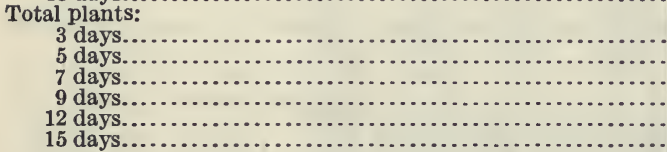 & $\begin{array}{r}246.6 \\
446.1 \\
461.7 \\
261.1 \\
113.9\end{array}$ & $\begin{array}{l}253.8 \\
441.2 \\
381.3 \\
396.8 \\
118.5 \\
113.3\end{array}$ & $\begin{array}{l}247.7 \\
369.3 \\
362.7 \\
335.7 \\
164.9 \\
100.9\end{array}$ & $\begin{array}{l}242.8 \\
414.4 \\
350.8 \\
379.3 \\
207.7 \\
133.8\end{array}$ \\
\hline
\end{tabular}

In the original seed there was no reducing sugar; 100 seeds contained, however, 0.095 gram of hydrolyzable sugar. During the process of growth the formation of reducing sugar in the seed is rapidly increased up to the fifth and sixth days. (See Table 14.) This is not only coincident with the breaking down of the hydrolyzable sugar, but is a result of the hydrolysis of the starch as well, inasmuch as a much larger amount of reducing sugars is found than could be accounted for by the original hydrolyzable sugar in the seed. After the fifth and sixth days there was a rapid falling off in the amount of reducing sugars found in the seed until at the end of the 15 th day the residual seed contained but a trace of this substance. In the axes, however, the reducing sugars increased up to about the ninth day, when they contained about three times as much of these sugars as the original seed did of hydrolyzable sugar.

After this period there is a gradual decrease in reducing sugars, even in the axes, until on the 15th day, the amount present approximated that of the hydrolyzable sugar originally present in the seed, namely, 0.095 gram per 100 plants.

The amount of reducing sugar found in the residual seed is somewhat higher in the control solution than under the influence of nitrogen, phosphoric acid, or potash. The greatest amount of reducing sugar was found on the ninth day in the axes of plants grown in the 
nitrate culture and the least in the potash solution. The disappearance of the reducing sugars is manifest in the control as well as in the culture medium. As will be noted, the hydrolyzable sugar has also entirely disappeared from the seed.

TABLE 15.-Hydrolyzable sugars (as dextrose) in residual seeds and axes when grown for 15 days in solutions containing one nutrient.

\begin{tabular}{|c|c|c|c|c|}
\hline Parts of plant and age. & $\begin{array}{l}\text { Control } \\
\text { solution. }\end{array}$ & $\begin{array}{l}\text { Nitrate } \\
\text { solution. }\end{array}$ & $\begin{array}{c}\text { Potash } \\
\text { solution. }\end{array}$ & $\begin{array}{l}\text { Phos- } \\
\text { phoric } \\
\text { acid solu- } \\
\text { tion. }\end{array}$ \\
\hline Original seed............ & $\mathrm{Mg}_{95}$ & $M_{95}$ & $M_{95}$ & Mg. $_{95}$ \\
\hline 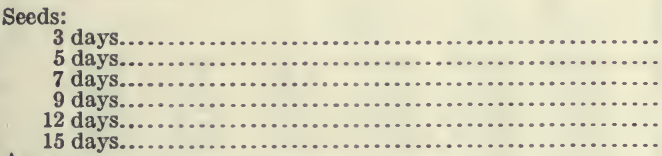 & $\begin{array}{r}60 \\
53 \\
60 \\
\text { Lost. } \\
\text { Trace. } \\
2\end{array}$ & $\begin{array}{r}55 \\
54 \\
51 \\
27 \\
1 \\
0 .\end{array}$ & $\begin{array}{r}69 \\
54 \\
59 \\
33 \\
0 \\
0\end{array}$ & $\begin{array}{r}60 \\
49 \\
39 \\
25 \\
14 \\
0\end{array}$ \\
\hline 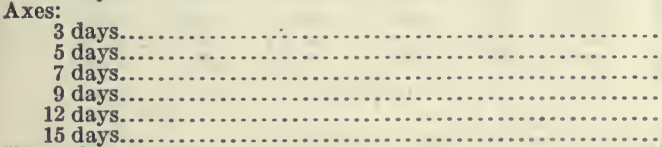 & $\begin{array}{l}50 \\
42 \\
46 \\
18 \\
60 \\
13\end{array}$ & $\begin{array}{r}48 \\
42 \\
46 \\
39 \\
22 \\
9\end{array}$ & $\begin{array}{l}48 \\
52 \\
76 \\
49 \\
61 \\
24\end{array}$ & $\begin{array}{l}43 \\
46 \\
50 \\
45 \\
52 \\
19\end{array}$ \\
\hline 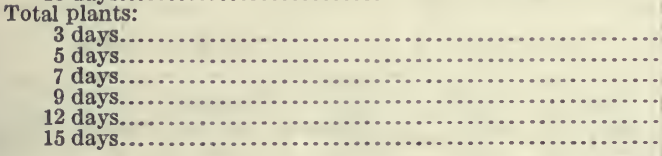 & $\begin{array}{r}110 \\
95 \\
106 \\
60 \\
60 \\
15\end{array}$ & $\begin{array}{r}103 \\
96 \\
97 \\
66 \\
23 \\
9\end{array}$ & $\begin{array}{r}117 \\
106 \\
135 \\
82 \\
61 \\
24\end{array}$ & $\begin{array}{r}103 \\
95 \\
89 \\
70 \\
66 \\
19\end{array}$ \\
\hline
\end{tabular}

Beginning with 95 milligrams of hydrolyzable sugar in 100 seeds, the decrease was steady and rapid, and on the 15th day no trace of sugar was found. There is no evidence of any new formation of hydrolyzable sugar in the seed, as no increase was observed at any time. The total amount found in the whole plant (seed + axes) never really exceeds that originally found in the seed, indicating either that the hydrolyzable sugar is translocated as such from the seed to the axes, or that it is hydrolyzed before translocation occurs. There is a small amount left in the axes on the fifteenth day. In the axes of three-day-old plants the amount of hydrolyzable sugar is about onehalf that in the original seed. This is gradually decreased until on the 15th day there is only a small amount left. These results are the same in the control solution as in the nutrient solutions.

There is no increase of hydrolyzable sugar in the seed, and while there is no reducing sugar present in the beginning, on the fifth day the amount of reducing sugar is twice that of the total hydrolyzable sugar present originally. That this increase in reducing sugar in the residual seed is the result of hydrolysis of the starch contained therein is most probable, but whether the sugars found in the axes are due entirely to the hydrolysis of the starch of the seed and subsequent translocation into the axes, or whether a part of these sugars is the result of assimilation, has not been determined. 


\section{APPENDIX.}

\section{DETAILED DATA ON WHICH SUMMARY TABLES IN TEXT ARE BASED.}

I. Plants grown in distilled water.

PLANT AXES (PLUMULE+ROOTLET).

\begin{tabular}{|c|c|c|c|c|c|c|c|c|}
\hline \multirow[b]{2}{*}{ Age of plant. } & \multicolumn{4}{|c|}{ Grams in 100 plants. } & \multicolumn{4}{|c|}{ Percentage in axes. } \\
\hline & Nitrogen. & $\begin{array}{l}\text { Phos- } \\
\text { phoric } \\
\text { acid. }\end{array}$ & Potash. & $\begin{array}{c}\text { Dry } \\
\text { weight. }\end{array}$ & Nitrogen. & $\begin{array}{l}\text { Phos- } \\
\text { phoric } \\
\text { acid. }\end{array}$ & Potash. & $\underset{\text { weight. }}{\text { Dry }}$ \\
\hline Original seed...... & 0.05108 & 0.0328 & 0.0194 & 3.495 & & & & \\
\hline 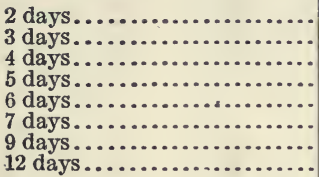 & $\begin{array}{l}.01174 \\
.01684 \\
.02414 \\
.03312 \\
.03986 \\
.04492 \\
.04996 \\
.04752\end{array}$ & $\begin{array}{l}.0055 \\
.0088 \\
.0108 \\
.0122 \\
.0166 \\
.0180 \\
.0232 \\
.0245\end{array}$ & $\begin{array}{l}.0073 \\
.0116 \\
.0190 \\
.0209 \\
.0209 \\
.0217 \\
.0252 \\
.0260\end{array}$ & $\begin{array}{l}.207 \\
.360 \\
.589 \\
.840 \\
1.035 \\
1.140 \\
1.549 \\
1.542\end{array}$ & $\begin{array}{l}23.0 \\
33.0 \\
47.2 \\
64.8 \\
78.0 \\
88.0 \\
97.7 \\
93.0\end{array}$ & $\begin{array}{l}16.8 \\
26.8 \\
32.9 \\
37.2 \\
50.6 \\
54.9 \\
70.8 \\
74.7\end{array}$ & $\begin{array}{r}37.6 \\
59.8 \\
98.0 \\
108.0 \\
108.0 \\
112.0 \\
130.0 \\
134.0\end{array}$ & $\begin{array}{r}6 \\
10 \\
17 \\
24 \\
30 \\
33 \\
44 \\
44\end{array}$ \\
\hline
\end{tabular}

SEEDS.

\begin{tabular}{|c|c|c|c|c|c|c|c|c|}
\hline \multirow[b]{2}{*}{ Age of plant. } & \multicolumn{4}{|c|}{ Grams in 100 residual seeds. } & \multicolumn{4}{|c|}{ Percentage left in seed. } \\
\hline & Nitrogen. & $\begin{array}{l}\text { Phos- } \\
\text { phoric } \\
\text { acid. }\end{array}$ & Potash. & $\begin{array}{c}\text { Dry } \\
\text { weight. }\end{array}$ & Nitrogen. & $\begin{array}{l}\text { Phos- } \\
\text { phoric } \\
\text { acid. }\end{array}$ & Potash. & $\begin{array}{c}\text { Dry } \\
\text { weight. }\end{array}$ \\
\hline Original seed... & 0.05108 & 0.0328 & 0.0194 & 3.495 & & & & \\
\hline 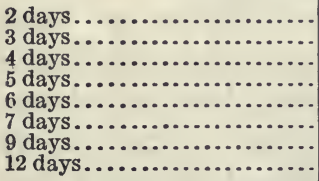 & $\begin{array}{l}.04436 \\
.03650 \\
.02976 \\
.02246 \\
.01964 \\
.01684 \\
.01236 \\
.00898\end{array}$ & $\begin{array}{l}.0268 \\
.0240 \\
.0215 \\
.0158 \\
.0143 \\
.0105 \\
.0067\end{array}$ & $\begin{array}{l}.0113 \\
.0102 \\
.0069 \\
.0043 \\
.0043 \\
.0023 \\
.0016 \\
.00077\end{array}$ & $\begin{array}{l}3.273 \\
2.910 \\
2.689 \\
2.178 \\
1.865 \\
1.622 \\
1.078 \\
.590\end{array}$ & $\begin{array}{l}86.8 \\
71.4 \\
58.2 \\
43.9 \\
38.4 \\
33.0 \\
24.2 \\
17.6\end{array}$ & $\begin{array}{l}81.7 \\
73.2 \\
65.5 \\
43.2 \\
43.6 \\
32.0 \\
20.4\end{array}$ & \begin{tabular}{r|}
58.3 \\
52.6 \\
35.6 \\
22.1 \\
22.1 \\
11.9 \\
8.3 \\
4.0
\end{tabular} & $\begin{array}{l}94 \\
83 \\
75 \\
62 \\
53 \\
46 \\
31 \\
17\end{array}$ \\
\hline
\end{tabular}

II. Plants grown in 64 parts per million phosphoric acid solution. (Plumule+rootlet.)

\begin{tabular}{|c|c|c|c|c|c|c|c|c|}
\hline \multirow[b]{2}{*}{ Age of plant. } & \multicolumn{4}{|c|}{ Grams in 100 plants. } & \multicolumn{4}{|c|}{ Percentage in axes. } \\
\hline & Nitrogen. & $\begin{array}{l}\text { Phos- } \\
\text { phoric } \\
\text { acid. }\end{array}$ & Potash. & $\begin{array}{c}\text { Dry } \\
\text { weight. }\end{array}$ & Nitrogen. & $\begin{array}{l}\text { Phos- } \\
\text { phoric } \\
\text { acid. }\end{array}$ & Potash. & $\begin{array}{c}\text { Dry } \\
\text { weight. }\end{array}$ \\
\hline 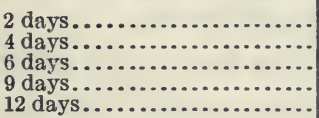 & $\begin{array}{l}0.01066 \\
.03312 \\
.04098 \\
.04771 \\
.04996\end{array}$ & $\begin{array}{l}0.0060 \\
.0157 \\
.0235 \\
.0296 \\
.0350\end{array}$ & $\begin{array}{r}0.0062 \\
.0171 \\
.0201 \\
.0217 \\
.0201\end{array}$ & $\begin{array}{l}0.189 \\
.809 \\
1.268 \\
1.536 \\
1.667\end{array}$ & $\begin{array}{l}20.9 \\
64.8 \\
80.2 \\
93.4 \\
97.8\end{array}$ & $\begin{array}{r}18.3 \\
47.9 \\
71.7 \\
90.2 \\
107.0\end{array}$ & $\begin{array}{r}32.0 \\
88.1 \\
104.0 \\
112.0 \\
104.0\end{array}$ & $\begin{array}{r}5 \\
23 \\
36 \\
44 \\
48\end{array}$ \\
\hline
\end{tabular}

GROWN IN DISTILLED WATER (CONTROL).

\begin{tabular}{|c|c|c|c|c|c|c|c|c|}
\hline Original seed................ & 0.05108 & 0.0328 & 0.0194 & 3.50 & . & ...... & $\ldots \ldots$ & $\ldots \ldots$ \\
\hline 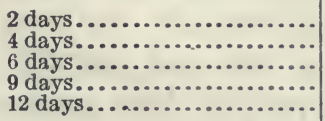 & $\begin{array}{l}.00954 \\
.0281 \\
.03761 \\
.04715 \\
.04771\end{array}$ & $\begin{array}{l}.0055 \\
.0107 \\
.0176 \\
.0210 \\
.0260\end{array}$ & $\begin{array}{l}.0058 \\
.0135 \\
.0201 \\
.0178 \\
.0207\end{array}$ & $\begin{array}{r}.179 \\
.689 \\
1.294 \\
1.435 \\
1.498\end{array}$ & $\begin{array}{l}18.6 \\
55.0 \\
73.6 \\
92.2 \\
93.4\end{array}$ & $\begin{array}{l}16.7 \\
32.6 \\
53.7 \\
64.0 \\
79.3\end{array}$ & $\begin{array}{r}29.9 \\
69.6 \\
104.0 \\
91.8 \\
107.0\end{array}$ & $\begin{array}{r}5 \\
20 \\
37 \\
41 \\
43\end{array}$ \\
\hline
\end{tabular}


III. Plants grown in 50 parts per million potash solution. (Plumule+rontlet.)

\begin{tabular}{|c|c|c|c|c|c|c|c|c|}
\hline \multirow[b]{2}{*}{ Age of plant. } & \multicolumn{4}{|c|}{ Grams in 100 plants. } & \multicolumn{4}{|c|}{ Percentage in axes. } \\
\hline & Nitrogen. & $\begin{array}{l}\text { Phos- } \\
\text { phoric } \\
\text { acid. }\end{array}$ & Potash. & $\begin{array}{c}\text { Dry } \\
\text { weight. }\end{array}$ & Nitrogen. & $\begin{array}{l}\text { Phos- } \\
\text { phoric } \\
\text { acid. }\end{array}$ & Potash. & $\begin{array}{c}\text { Dry } \\
\text { weight. }\end{array}$ \\
\hline 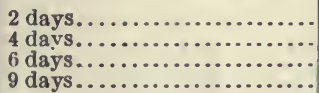 & $\begin{array}{r}0.01290 \\
.02750 \\
.04828 \\
.04658\end{array}$ & $\begin{array}{l}0.0074 \\
.0131 \\
.0150 \\
.0244\end{array}$ & $\begin{array}{l}0.0074 \\
.0256 \\
.0356 \\
.0607\end{array}$ & $\begin{array}{c}0.3087 \\
.7470 \\
.8600 \\
1.444\end{array}$ & $\begin{array}{l}25.2 \\
53.8 \\
94.5 \\
91.2\end{array}$ & $\begin{array}{l}22.6 \\
39.9 \\
45.7 \\
74.4\end{array}$ & $\begin{array}{r}38.1 \\
132.0 \\
183.0 \\
313.0\end{array}$ & $\begin{array}{r}9 \\
21 \\
25 \\
41\end{array}$ \\
\hline
\end{tabular}

GROWN IN DISTILLED WATER (CONTROL).

\begin{tabular}{|c|c|c|c|c|c|c|c|c|}
\hline Original seed............... & 0.05108 & 0.0328 & 0.0194 & 3.50 & & & & \\
\hline 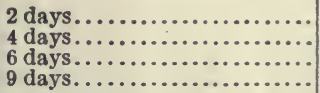 & $\begin{array}{l}.01402 \\
.02974 \\
.04434 \\
.04602\end{array}$ & $\begin{array}{l}.0080 \\
.0131 \\
.0142 \\
.0202\end{array}$ & $\begin{array}{l}.0071 \\
.0154 \\
.0169 \\
.0202\end{array}$ & $\begin{array}{l}.3456 \\
.8454 \\
.914 \\
1.256\end{array}$ & $\begin{array}{l}27.4 \\
58.2 \\
86.8 \\
90.1\end{array}$ & $\begin{array}{l}24.4 \\
39.9 \\
43.3 \\
61.6\end{array}$ & $\begin{array}{r}36.6 \\
79.4 \\
87.1 \\
104.0\end{array}$ & $\begin{array}{l}10 \\
24 \\
26 \\
36\end{array}$ \\
\hline
\end{tabular}

IV. Plants grown in 150 parts per million potash solution. (Plumule+rootlet.)

\begin{tabular}{|c|c|c|c|c|c|c|c|c|}
\hline \multirow[b]{2}{*}{ Age 0} & \multicolumn{4}{|c|}{ Grams in 100 plants. } & \multicolumn{4}{|c|}{ Percentage in axes. } \\
\hline & Nitrogen. & $\begin{array}{l}\text { Phos- } \\
\text { phoric } \\
\text { acid. }\end{array}$ & Potash. & $\begin{array}{c}\text { Dry } \\
\text { weight. }\end{array}$ & Nitrogen. & $\begin{array}{l}\text { Phos- } \\
\text { phoric } \\
\text { acid. }\end{array}$ & Potash. & $\begin{array}{c}\text { Dry } \\
\text { weight. }\end{array}$ \\
\hline 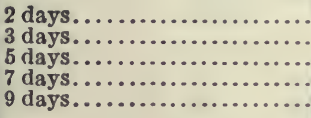 & $\begin{array}{r}0.01347 \\
.02189 \\
.04266 \\
.04603 \\
.04435\end{array}$ & $\begin{array}{r}0.0078 \\
.0105 \\
.0210 \\
.0257 \\
.0278\end{array}$ & $\begin{array}{l}0.0078 \\
.0178 \\
.0481 \\
.0509 \\
.0558\end{array}$ & $\begin{array}{l}0.287 \\
.521 \\
1.234 \\
1.466 \\
1.740\end{array}$ & $\begin{array}{l}26.4 \\
42.9 \\
83.6 \\
90.1 \\
86.8\end{array}$ & $\begin{array}{l}23.8 \\
32.0 \\
64.0 \\
78.3 \\
84.8\end{array}$ & $\begin{array}{r}40.2 \\
91.8 \\
247.0 \\
262.0 \\
288.0\end{array}$ & $\begin{array}{r}8 \\
15 \\
35 \\
42 \\
50\end{array}$ \\
\hline
\end{tabular}

GROWN IN DISTILLED WATER (CONTROL).

\begin{tabular}{|c|c|c|c|c|c|c|c|c|}
\hline Original seed.. & 0.05108 & 0.0328 & 0.0194 & 3.50 & & & & \\
\hline 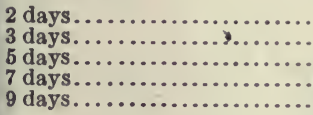 & $\begin{array}{l}.01415 \\
.02302 \\
.04379 \\
.04854 \\
\text { Lost. }\end{array}$ & $\begin{array}{l}.0065 \\
.0100 \\
.0210 \\
.0245 \\
.0255\end{array}$ & $\begin{array}{l}.0062 \\
.00103 \\
.0217 \\
.0231 \\
.0231\end{array}$ & $\begin{array}{r}.232 \\
.470 \\
1.185 \\
1.454 \\
1.526\end{array}$ & $\begin{array}{l}27.7 \\
45.1 \\
85.8 \\
95.6\end{array}$ & $\begin{array}{l}19.8 \\
30.5 \\
64.0 \\
74.7 \\
77.7\end{array}$ & $\begin{array}{r}31.9 \\
53.1 \\
112.0 \\
119.0 \\
119.0\end{array}$ & $\begin{array}{r}7 \\
13 \\
34 \\
41 \\
44\end{array}$ \\
\hline
\end{tabular}

V.-Plants grown in 100 parts per million nitrate solution. (Plumule+rootlet.)

\begin{tabular}{|c|c|c|c|c|c|c|c|c|}
\hline \multirow[b]{2}{*}{ Age of plant. } & \multicolumn{4}{|c|}{ Grams in 100 plants. } & \multicolumn{4}{|c|}{ Percentage in axes. } \\
\hline & Nitrogen. & $\begin{array}{l}\text { Phos- } \\
\text { phoric } \\
\text { acid. }\end{array}$ & Potash. & $\begin{array}{c}\text { Dry } \\
\text { weight. }\end{array}$ & Nitrogen. & $\begin{array}{l}\text { Phos- } \\
\text { phoric } \\
\text { acid. }\end{array}$ & Potash. & $\begin{array}{c}\text { Dry } \\
\text { weight. }\end{array}$ \\
\hline $\begin{array}{l}2 \text { days... } \\
3 \text { days... } \\
5 \text { days... } \\
7 \text { days... } \\
9 \text { days... }\end{array}$ & $\begin{array}{r}0.01852 \\
.02806 \\
.04658 \\
.06904 \\
.06680\end{array}$ & $\begin{array}{r}0.0088 \\
.0110 \\
.0180 \\
.0226 \\
.0270\end{array}$ & $\begin{array}{c}0.0088 \\
.0129 \\
.0180 \\
\cdots .0192 \\
.0192\end{array}$ & $\begin{array}{l}0.385 \\
.629 \\
1.168 \\
1.622 \\
1.706\end{array}$ & $\begin{array}{r}36.2 \\
55.0 \\
91.2 \\
135.0 \\
131.0\end{array}$ & $\begin{array}{l}26.8 \\
35.5 \\
54.9 \\
68.9 \\
82.3\end{array}$ & $\begin{array}{c}45.4 \\
66.5 \\
92.8 \\
\dddot{99.0}\end{array}$ & $\begin{array}{l}11 \\
18 \\
33 \\
46 \\
49\end{array}$ \\
\hline \multicolumn{9}{|c|}{ GROWN IN DISTILLED WATER (CONTROL). } \\
\hline Original seed.. & 0.05108 & 0.0328 & 0.0194 & 3. 50 & & & & \\
\hline $\begin{array}{l}2 \text { days. } \\
3 \text { days.. } \\
5 \text { days.. } \\
7 \text { days.. } \\
9 \text { days.. }\end{array}$ & $\begin{array}{c}.01740 \\
.041134 \\
.05108 \\
.04659\end{array}$ & $\begin{array}{r}.0110 \\
.0125 \\
.0175 \\
.0230 \\
.0236\end{array}$ & $\begin{array}{c}.0091 \\
.0130 \\
.0161 \\
.0173\end{array}$ & $\begin{array}{r}.440 \\
.660 \\
1.101 \\
1.548 \\
1.490\end{array}$ & $\begin{array}{r}34.1 \\
3 \ldots 1.4 \\
100.0 \\
91.2\end{array}$ & $\begin{array}{l}35.5 \\
38.1 \\
53.3 \\
70.1 \\
71.9\end{array}$ & \begin{tabular}{c}
46.9 \\
67.0 \\
83.0 \\
\hdashline 89.2
\end{tabular} & $\begin{array}{l}13 \\
19 \\
31 \\
44 \\
43\end{array}$ \\
\hline
\end{tabular}


VI.-Plants grown in 150 parts per million phosphoric acid solution. (Plumule+ rootlet.)

\begin{tabular}{|c|c|c|c|c|c|c|c|c|}
\hline \multirow[b]{2}{*}{ Age of plant. } & \multicolumn{4}{|c|}{ Grams in 100 plants. } & \multicolumn{4}{|c|}{ Percentage in axes. } \\
\hline & Nitrogen. & $\begin{array}{l}\text { Phos- } \\
\text { phoric } \\
\text { acid. }\end{array}$ & Potash. & $\begin{array}{c}\text { Dry } \\
\text { weight. }\end{array}$ & Nitrogen. & $\begin{array}{l}\text { Phos- } \\
\text { phoric } \\
\text { acid. }\end{array}$ & Potash. & $\begin{array}{c}\text { Dry } \\
\text { weight. }\end{array}$ \\
\hline 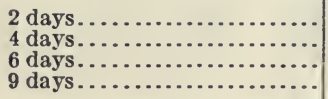 & $\begin{array}{r}0.01572 \\
.03368 \\
.04266 \\
.04603\end{array}$ & $\begin{array}{r}0.0080 \\
.0207 \\
.0280 \\
.0355\end{array}$ & $\begin{array}{r}0.0080 \\
.0178 \\
.0178 \\
.0217\end{array}$ & $\begin{array}{r}0.322 \\
.926 \\
1.361 \\
1.654\end{array}$ & $\begin{array}{l}30.7 \\
66.0 \\
83.5 \\
90.1\end{array}$ & $\begin{array}{r}24.4 \\
63.1 \\
85.4 \\
108.0\end{array}$ & $\begin{array}{r}41.2 \\
91.8 \\
91.8 \\
112.0\end{array}$ & $\begin{array}{r}9 \\
26 \\
39 \\
47\end{array}$ \\
\hline
\end{tabular}

GROWN IN DISTILLED WATER (CONTROL).

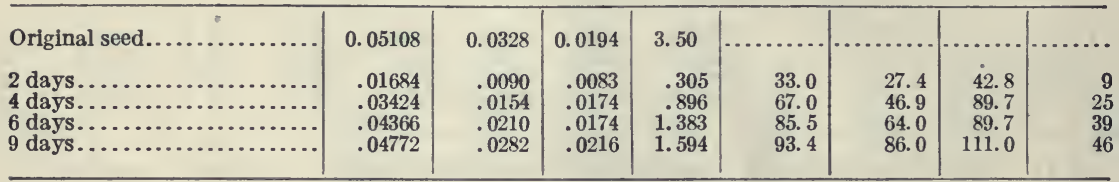

VII.-Plants grown in 150 parts per million nitrate solution. (Plumule+rontlet.)

\begin{tabular}{|c|c|c|c|c|c|c|c|c|}
\hline \multirow[b]{2}{*}{ Age of plant. } & \multicolumn{4}{|c|}{ Grams per 100 plants. } & \multicolumn{4}{|c|}{ Percentage in axes. } \\
\hline & Nitrogen. & $\begin{array}{l}\text { Phos- } \\
\text { phoric } \\
\text { acid. }\end{array}$ & Potash. & $\begin{array}{c}\text { Dry } \\
\text { weight. }\end{array}$ & Nitrogen. & $\begin{array}{l}\text { Phos- } \\
\text { phoric } \\
\text { acid. }\end{array}$ & Potash. & $\begin{array}{c}\text { Dry } \\
\text { weight. }\end{array}$ \\
\hline 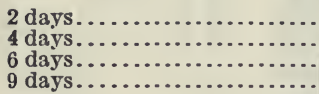 & $\begin{array}{r}0.0148 \\
.0284 \\
.0474 \\
.0600\end{array}$ & $\begin{array}{l}0.0071 \\
.0125 \\
.0195 \\
.0277\end{array}$ & $\begin{array}{r}0.0070 \\
.0128 \\
.0178 \\
.0202\end{array}$ & $\begin{array}{l}0.259 \\
.654 \\
1.270 \\
1.456\end{array}$ & $\begin{array}{r}29.0 \\
55.6 \\
92.8 \\
117.0\end{array}$ & $\begin{array}{l}21.6 \\
38.1 \\
59.4 \\
84.4\end{array}$ & $\begin{array}{r}36.1 \\
66.0 \\
91.8 \\
104.0\end{array}$ & $\begin{array}{r}7 \\
19 \\
36 \\
41\end{array}$ \\
\hline
\end{tabular}

GROWN IN DISTILLED WATER (CONTROL).

\begin{tabular}{|c|c|c|c|c|c|c|c|c|}
\hline Original seed............... & 0.05108 & 0.0328 & 0.0186 & 3.50 & & & & \\
\hline 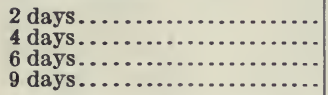 & $\begin{array}{l}.0132 \\
.0260 \\
.0408 \\
.0446\end{array}$ & $\begin{array}{l}.0070 \\
.0120 \\
.0195 \\
.0240\end{array}$ & $\begin{array}{l}.0068 \\
.0116 \\
.0180 \\
.0186\end{array}$ & $\begin{array}{r}.236 \\
.556 \\
1.273 \\
1.294\end{array}$ & $\begin{array}{l}25.8 \\
50.9 \\
79.9 \\
87.3\end{array}$ & $\begin{array}{l}21.3 \\
36.6 \\
59.4 \\
73.2\end{array}$ & $\begin{array}{l}35.1 \\
59.8 \\
92.8 \\
95.8\end{array}$ & $\begin{array}{r}7 \\
16 \\
36 \\
37\end{array}$ \\
\hline
\end{tabular}



